Article

\title{
Modulus and Strength of Concretes with Alternative Materials
}

\author{
Ana Elisabete Paganelli Guimarães de Avila Jacintho *, Ivanny Soares Gomes Cavaliere, \\ Lia Lorena Pimentel and Nádia Cazarim Silva Forti
}

Exact Sciences, Environmental and Technologies Center, Pontifical Catholic University of Campinas (PUC-Campinas), Campinas 13086-099, Brazil; ivannycavaliere@gmail.com (I.S.G.C.); lialp@puc-campinas.edu.br (L.L.P.); nadia.cazarim@puc-campinas.edu.br (N.C.S.F.)

* Correspondence: anajacintho@puc-campinas.edu.br; Tel.: +55-19-99603-0397

Received: 1 September 2020; Accepted: 23 September 2020; Published: 1 October 2020

\begin{abstract}
This paper presents a study with concretes produced with natural aggregates, recycled concrete aggregates (RCA) and waste porcelain aggregates (WPA). The study analyzed the influence of recycled aggregates in the mechanical properties of conventional concretes and evaluated the difference between measured and predicted values of elasticity modulus. The incorporation of WPA in concrete showed better mechanical results compared to the concretes produced with RCA. Measured elasticity moduli were lower than moduli predicted by NBR 6118:2014 and fib Model Code 2010, while measured results were greater than values predicted by Eurocode 2:2004 and ACI 318:2014, as expected, which indicated the safety of the latter two standards.
\end{abstract}

Keywords: concrete; natural aggregates; recycled concrete aggregates; waste porcelain aggregates; elasticity modulus

\section{Introduction}

Due to the exponential growth of the population, the construction industry has been highly demanded to attend society by building new constructions. Therefore, the construction industry is considered one of the main sectors with negative environmental impact, since it consumes huge amounts of non-renewable natural resources and generates an extensive volume of construction and demolition wastes [1-3].

In Brazil, it is estimated 45 million tons of construction and demolition waste (C\&DW) are collected by the Brazilian municipalities annually, representing $58 \%$ of the total solid urban waste generated [4]. The incorrect disposal of these huge amounts of wastes has caused many environmental and social problems, as they compromise the urban landscape, contaminate the soil and contribute to clogging the urban drainage systems $[2,5]$.

Instead of using natural aggregates in the production of new concrete, a viable alternative is using recycled aggregates obtained from construction and demolition waste [3,6]. Many studies recognize concretes composed of recycled aggregates as coarse and/or fine fractions, with similar mechanical properties to conventional concretes [7-9]. There was a study on an "ecological concrete" for structural use made by Brazilian and Italian researchers in 2004 [10]. The use of recycled aggregates in structural concretes can only be widely adopted by the construction industry if the concrete design parameters are well studied [11].

The elasticity modulus of concrete is a fundamental parameter in concrete structure design because it is possible to predict the structural behavior in service under load action and determine the deformations and displacements distribution [12,13]. 
To relate the experimental values with predicted values from standards, it is always necessary to validate the research and the standards indication, as the authors of [14] did with their columns of confined concrete. Several different prediction equations have been proposed to calculate concrete elasticity modulus from its compressive strength, but it is also possible to determine it by mechanical tests $[11,13]$. The elasticity modulus values obtained in experimental tests, as with other design parameters of concretes structures, differ from those predicted by empirical equations proposed by standards, even though the formulations consider graphs made up of empirical values [11,13-18].

These values cannot differ significantly, as a slight change in modulus translates to a slight difference in the deformation of a structure, and thus a lack of accuracy between experimental and predicted modulus can reflect in an under- or overdesign of concrete structures [13].

Accordingly, this study aimed to study the modulus of elasticity of concretes with compressive strength of 20 and $40 \mathrm{MPa}$ with partial replacement rates (30\% and $50 \%$ ) of basaltic coarse aggregates by recycled concrete aggregates (RCA) and waste porcelain aggregates (WPA), as well as evaluate the difference between the values of measured and predicted modulus calculated by the Brazilian standard NBR 6118:2014 [19], fib Model Code 2010 [20], Eurocode 2:2004 [21] and ACI 318:2014 [22].

Thus, this study, in contrast to those mentioned above, showed the possible use of national and international standards for structural projects, with conventional strength concrete made with certain recycled aggregates.

\section{Materials and Methods}

The purpose of this research was to investigate the mechanical properties of concretes with moderate strength because moderate strength concretes are frequently used in reinforced concrete construction. The Brazilian standard NBR 8953:2015 [23] classifies these concretes in Group 1 with a characteristic compressive strength $\left(\mathrm{f}_{\mathrm{ck}}\right)$ ranging from 10 to $50 \mathrm{MPa}$.

Thus, two groups of concretes were produced: $20 \mathrm{MPa}$ and $40 \mathrm{MPa}$ concretes. For each group, different coarse aggregates were used with replacement rates of $30 \%$ and $50 \%$ : natural aggregates (NCA), that was basalt from Campinas, Brazil; recycled concrete aggregates (RCA), made by waste concrete from PUC Campinas laboratory; and waste porcelain aggregates (WPA), of a porcelain factory of electrical insulators in the city of Pedreira, Brazil.

The notation of all concretes was denominated as shown Figure 1. First, the compressive strength (20 or $40 \mathrm{MPa}$ ) is displayed, then the type of coarse aggregate incorporated (RCA or WPA) and finally the replacement rate $(30 \%$ or $50 \%)$. Conventional concretes or reference concretes, with only natural aggregates, are named as $\mathrm{C} 20$ or $\mathrm{C} 40$ depending on the compressive strength group.

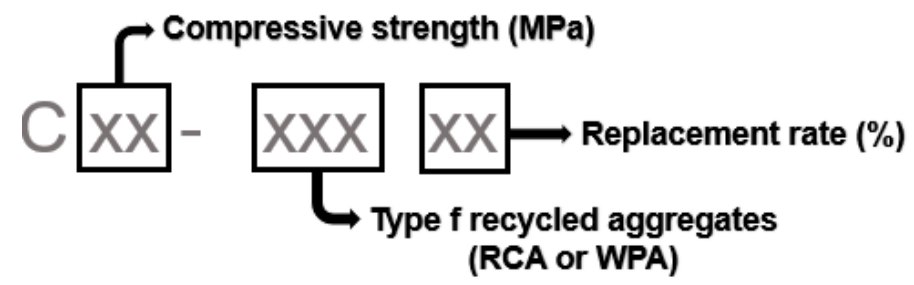

Figure 1. Concrete compositions classification.

The present study followed the flowchart displayed in Figure 2. The waste materials were recycled, the employed materials were characterized, the concretes mix proportions were decided, the mixtures were cast in cylinder and cube specimens, the mechanical tests of specimens were carried out, the concretes' mechanical properties were predicted from formulations proposed by standards, all the data were analyzed and the final considerations were concluded.

The specimen's preparation and mechanical tests were executed at the Construction Materials and Structures Laboratory from Pontifical Catholic University of Campinas, Brazil. 


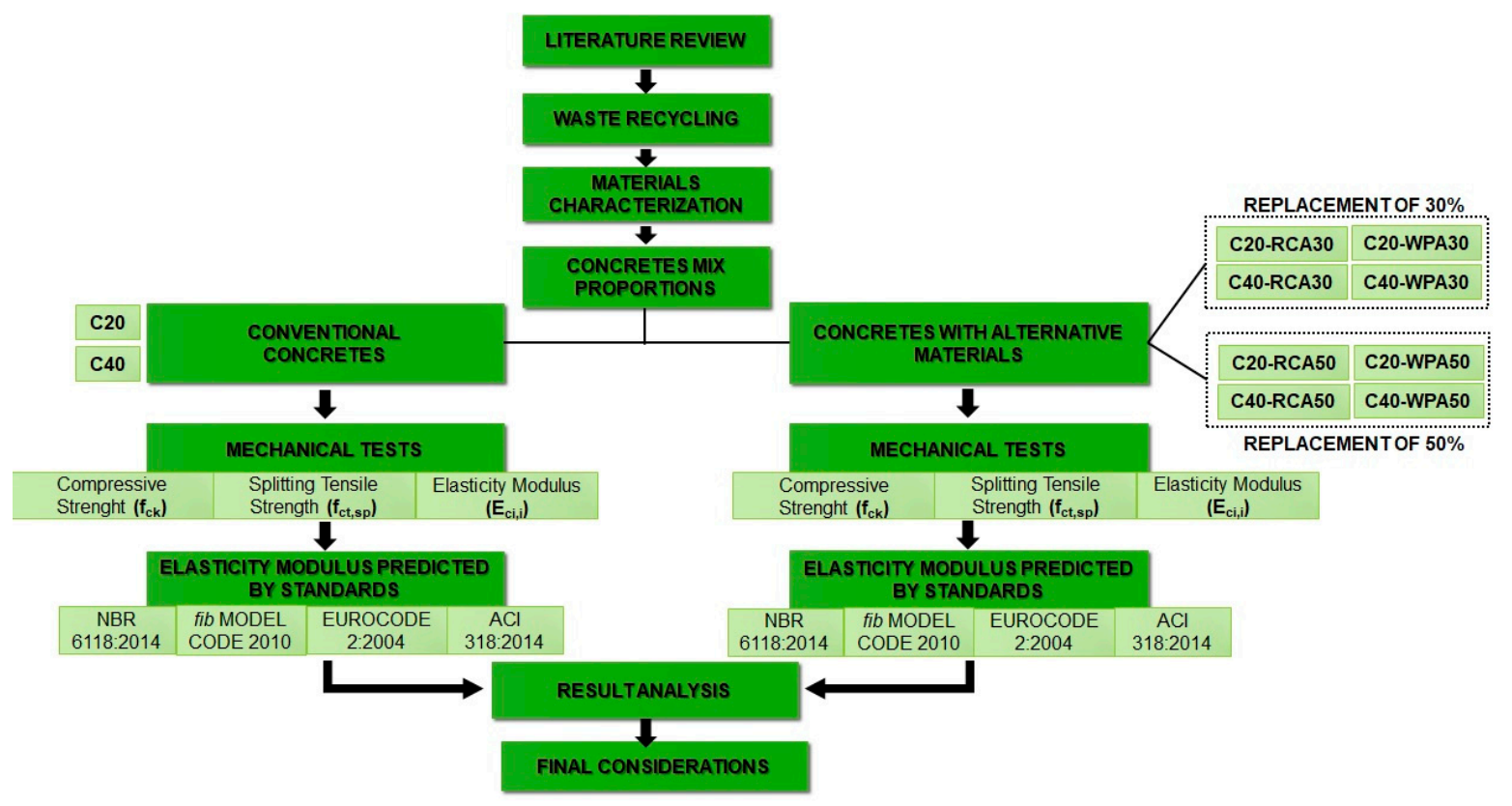

Figure 2. Research activities flowchart.

\subsection{Materials Selection and Characterization}

For concretes, production used the following constituent materials: rapid hardening cement (Brazilian type cement CP V ARI, LafargeHolcim, Santo André, Brazil) with a density of $3.13 \mathrm{~g} / \mathrm{cm}^{3}$; fine natural aggregate (FNA) that was quartzite sand from Campinas, Brasil; coarse natural aggregate (CNA) that was basalt from Campinas, Brazil; recycled concrete aggregates (RCA), made by waste concrete from PUC Campinas laboratory; waste porcelain aggregates (WPA), of a porcelain factory of electrical insulators in the city of Pedreira, Brazil; plasticizer, from GCP Applied Technology, Sorocaba, Brazil and water from Campinas city. The CNA was basaltic gravel, whereas the FNA was quartzite sand, both of which are the most widely-used aggregates in the state of São Paulo, Brazil.

Two plasticizers were employed in the concretes: a water reducer from GCP Applied Technology, Sorocaba, Brazil and water from Campinas city for the $20 \mathrm{MPa}$ concretes and a polycarboxylic ether-based superplasticizer, from GCP Applied Technology, Sorocaba, Brazil and water from Campinas city for the $40 \mathrm{MPa}$ concretes. The plasticizer's producers suggest a dosage between $0.6 \%$ and $1.0 \%$ upon cement consumption when using the water reducer plasticizer and a dosage between $0.15 \%$ and $0.80 \%$ when using the superplasticizer.

The recycling process of concrete and porcelain waste consisted of crushing the porcelain into small pieces using a hammer and then crushing the small pieces in a jaw crusher (Contenco Industry, São José da Lapa, Minas Gerais, Brazil). Four samples of $5 \mathrm{~kg}$ of each waste were crushed. The samples were bent for the particle size analysis to determine a grading curve for the recycled coarse aggregates as similar as possible to the natural coarse aggregates. Figure 3 exhibits the whole process of recycling.
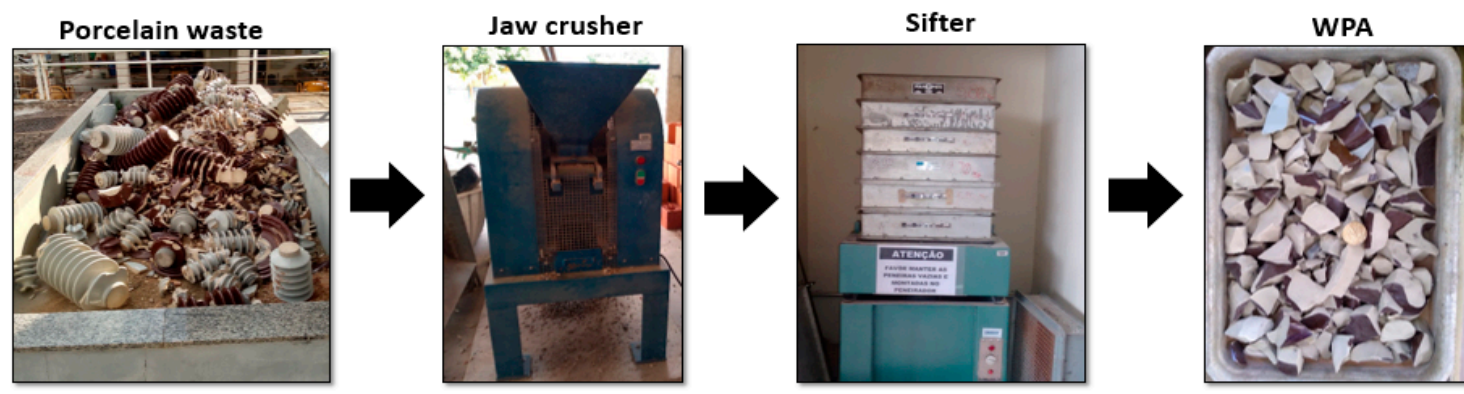

Figure 3. Recycling process of electrical porcelain insulators. 
During the crushing process of concrete waste, it was seen that some gravels were detached from the mortar of the concrete waste; thus, some gravels returned to their original natural aggregate, but still surrounded by a fine old cement paste. In the porcelain waste crushing, great care was required during handling due to the splinters caused by breaking it.

Figure 4 illustrates a visual difference between natural and recycled aggregates. The physical properties of natural and recycled aggregates are assembled in Table 1, including the standards consulted to realize the experiments. Figure 5 shows the fine aggregates distribution curves and Figure 6 shows the coarse aggregates distribution curves with their respective limits implied by NBR NM 248:2003 [24].

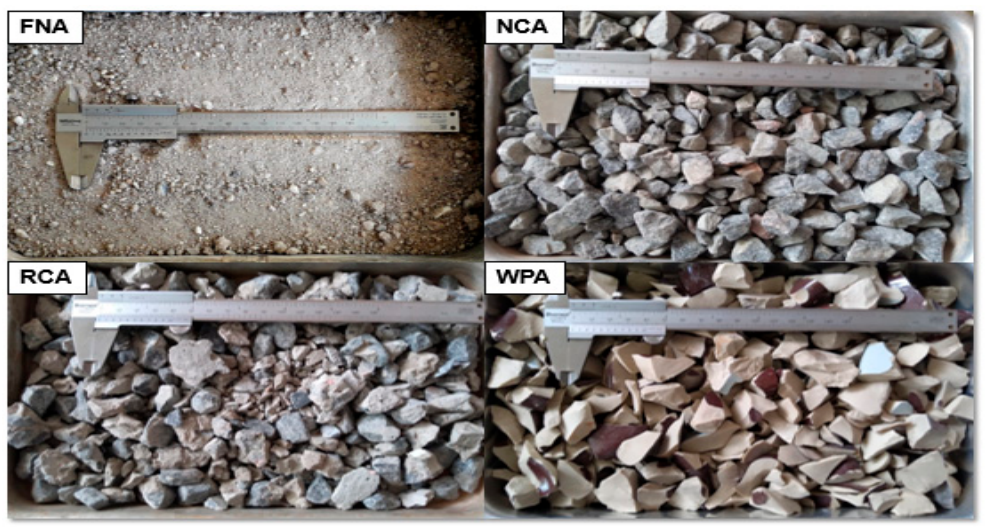

Figure 4. Comparison between natural and recycled aggregates.

Table 1. Properties of natural and recycled aggregates.

\begin{tabular}{ccccc}
\hline \multirow{2}{*}{ Properties } & \multicolumn{2}{c}{ Natural Aggregates } & \multicolumn{2}{c}{ Recycled Aggregates } \\
\cline { 2 - 5 } & NFA & NCA & RCA & WPA \\
\hline Particle size $(\mathrm{mm})$ & 4.75 & 25.00 & 25.00 & 25.00 \\
Fineness modulus & 2.43 & 6.97 & 6.63 & 1.87 \\
Density $\left(\mathrm{g} / \mathrm{cm}^{3}\right)$ & 2.53 & 2.74 & 2.39 & 2.34 \\
Loose bulk density $\left(\mathrm{g} / \mathrm{cm}^{3}\right)$ & 1.50 & 1.46 & 1.22 & 1.21 \\
Compacted bulk density $\left(\mathrm{g} / \mathrm{cm}^{3}\right)$ & 1.64 & 1.50 & 1.30 & 1.29 \\
Void index rate $(\%)$ & ND & 99.95 & 99.95 & 99.95 \\
Water absorption rate $(\%)$ & ND & 0.68 & 6.81 & 0.39 \\
Powder content rate $(\%)$ & 77.69 & 99.50 & 97.02 & 99.92 \\
\hline
\end{tabular}

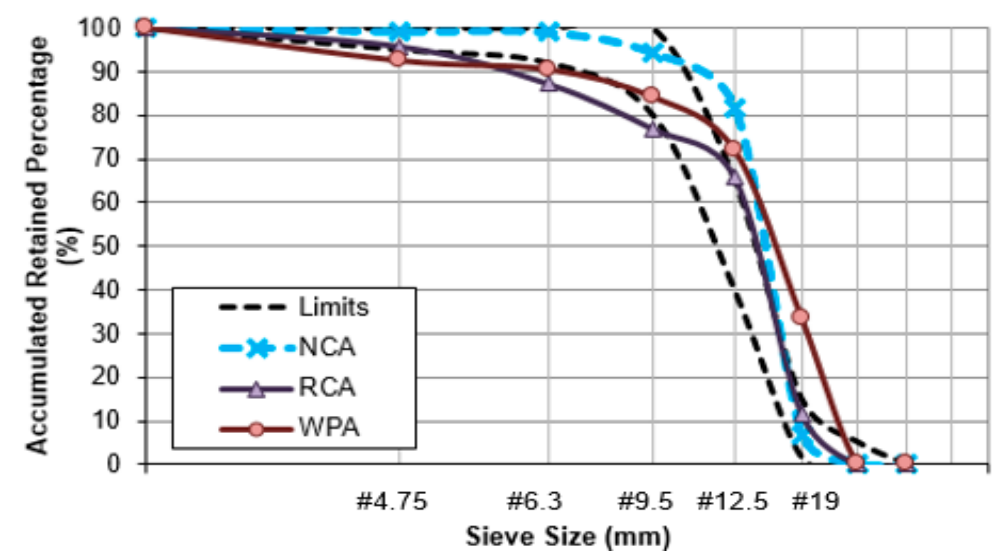

Figure 5. Gradation curves of recycled concrete aggregates (RCA) and waste porcelain aggregates (WPA) in comparison to natural coarse aggregate (NCA). 


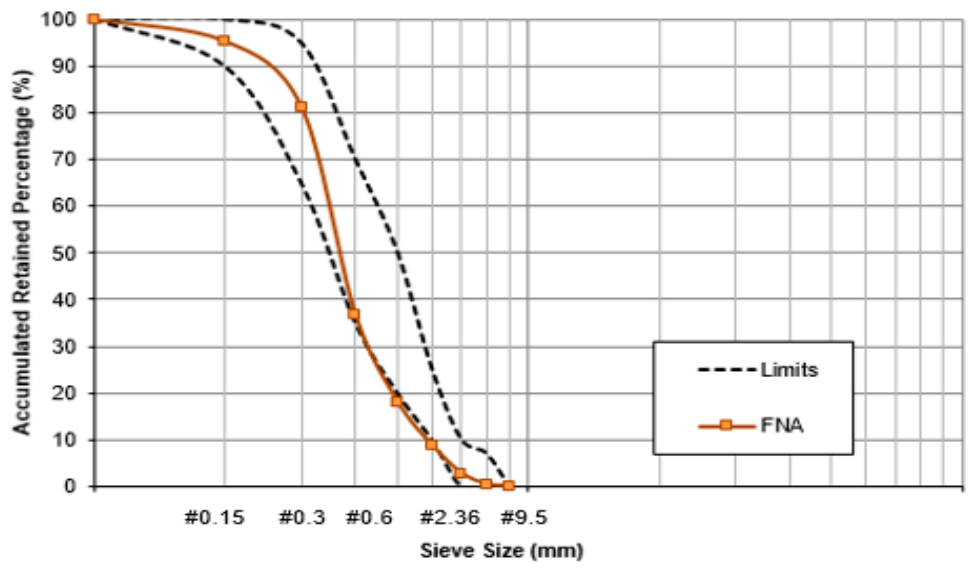

Figure 6. Gradation curves of fine natural aggregates (FNA).

\subsection{Mix Design Proportions and Specimen Preparation}

Table 2 lists the concrete proportions. The mix design proportions were based on the modified IPT method [25].

Table 2. Concretes mix proportions.

\begin{tabular}{|c|c|c|c|c|c|c|c|c|c|c|}
\hline Proportions & $\mathrm{C} 20$ & C20-RCA30 & C20-RCA50 & C20-WPA30 & C20-WPA50 & $\mathrm{C} 40$ & C40-RCA30 & C40-RCA50 & C40-WPA30 & C40-WPA50 \\
\hline Cement & 1.00 & 1.00 & 1.00 & 1.00 & 1.00 & 1.00 & 1.00 & 1.00 & 1.00 & 1.00 \\
\hline FNA & 2.42 & 2.42 & 2.42 & 2.42 & 2.42 & 2.10 & 2.10 & 2.10 & 2.10 & 2.10 \\
\hline CNA & 2.58 & 1.81 & 1.29 & 1.81 & 1.29 & 2.90 & 2.03 & 1.45 & 2.03 & 1.45 \\
\hline Water/cement ratio & 0.60 & 0.50 & 0.50 & 0.50 & 0.50 & 0.40 & 0.40 & 0.40 & 0.40 & 0.40 \\
\hline $\begin{array}{c}\text { Plasticizer (\%) } \\
\text { Cement }\end{array}$ & 0.760 & 0.368 & 1.000 & 0.563 & 0.750 & 0.750 & 0.750 & 0.750 & 0.750 & 0.750 \\
\hline $\begin{array}{c}\text { consumption } \\
\left(\mathrm{kg} / \mathrm{m}^{3}\right)\end{array}$ & 354.91 & 367.97 & 367.97 & 367.97 & 367.97 & 388.88 & 388.88 & 388.88 & 388.88 & 388.88 \\
\hline
\end{tabular}

In particular, the natural coarse aggregates (NCA) were volumetrically replaced with recycled coarse aggregates (RCA and WPA) with replacements rates of $0 \%, 30 \%$ and $50 \%$. The quantity of both recycled coarse aggregates was adjusted according to the relation of recycled aggregates density to natural aggregates density.

Furthermore, 0.60 water/cement ratio was employed for $20 \mathrm{MPa}$ reference concretes and 0.40 for $40 \mathrm{MPa}$ reference concretes. For concretes containing recycled aggregates, the water/cement ratios were reduced, expecting a possible reduction of their mechanical properties. In the case of $40 \mathrm{MPa}$ concretes, the water/cement ratio remained the same because of the different plasticizer used: a water reducer plasticizer was used for $20 \mathrm{MPa}$ concretes, while $40 \mathrm{MPa}$ concretes used a superplasticizer. At the moment of molding the specimens with $40 \mathrm{MPa}$ concrete, there was not enough plasticity to mold the specimens adequately and the prior plasticizer adopted (water reducer plasticizer) had to be changed to a different one (superplasticizer).

The Brazilian standard NBR 15116:2004 [26] prescribes the inclusion of pre-soaked water in concretes with RCA as RCA diminishes water absorption and slightly reduces their mechanical properties. Therefore, for RCA concretes, $60 \%$ pre-soaked water over RCA water absorption capacity was inserted. For WPA concretes, it was decided not to adopt pre-soaked water as porcelain water absorption capacity is too low.

The concretes mix procedure pursued a sequence of events. First, the concrete mixer was moistened. The kneading water was separated into two portions: in the first portion, two parts of plasticizer was incorporated, and, in the second portion, only one part was incorporated. As plasticizer total amount was divided into four parts, the last part was saved in case it would not be possible to mold the specimens. Subsequently, all coarse aggregates and the first portion of kneading water was added, the cement was also included and those present materials were mixed. The fine natural 
aggregates and the second portion of kneading water were added, and, finally, the whole mixture was mixed for $5 \mathrm{~min}$. At last, a slump test was performed only to investigate if mortar content was adequate, and, in the case it was not, new parts of plasticizer were carefully added considering the producer specified dosage. Figure 7 illustrates how materials were separated; the two blue buckets represent the kneading water and the red bucket represents the pre-soaked water.

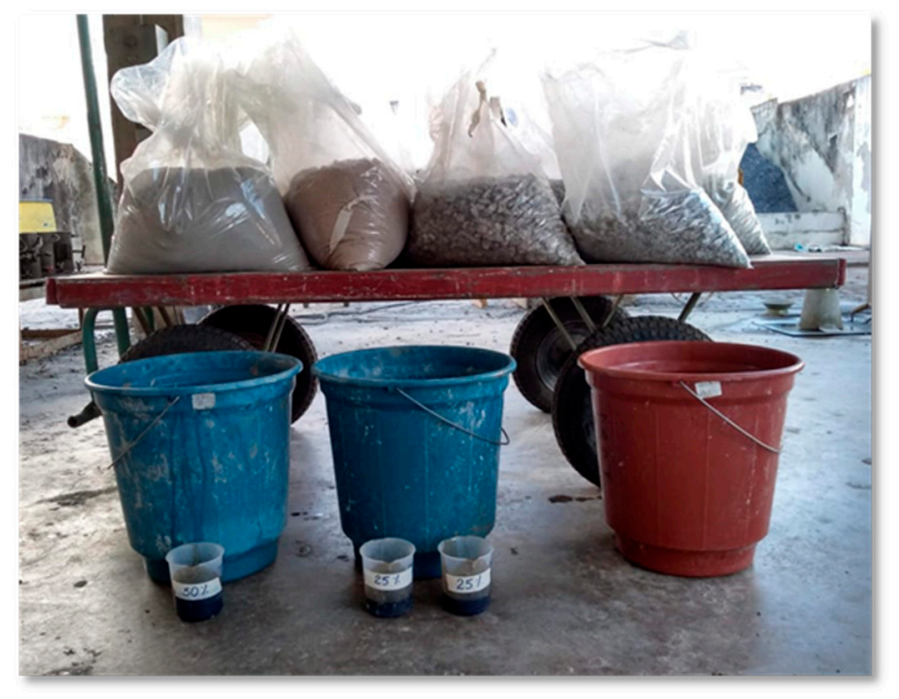

Figure 7. Materials separation for concrete production.

\subsection{Mechanical Testing}

Concrete specimens were cast, while a vibrating table was used to compact the concrete. For each concrete mixture, thirty $100 \mathrm{~mm} \times 200 \mathrm{~mm}$ cylindrical specimens and six $100 \mathrm{~mm}$ cubic specimens were prepared. In particular, cylindrical specimens were used to measure the compressive strength $\left(\mathrm{f}_{\mathrm{cm}, \mathrm{cyl}}\right)$ (six specimens for 7 days old and six specimens for 28 days old), the elasticity modulus $\left(\mathrm{E}_{\mathrm{cm}}\right)$ (six specimens for 7 days old and six specimens for 28 days old) and the splitting tensile strength $\left(\mathrm{f}_{\mathrm{ctm}, \mathrm{sp}}\right)$ (six specimens for 28 days old). Cubic specimens were used only to test compressive strength at 28 days old and compare with values of compressive strength tested with cylindrical specimens.

The values of measured elasticity modulus were associated with initial tangent modulus; hence, the measured initial tangent modulus must be compared to the predicted tangent modulus.

\subsection{Analysis of Variance (ANOVA)}

Single-factor ANOVA was developed by Fisher (1890-1962) and consists of observing possible differences between two or more samples averages at a 5\% level of significance [27]. ANOVA's response is obtained from hypothesis testing that can be performed by $p$-value. $P$-value is designated as the probability of any sample average being more distant than the other samples' average. $P$-value evaluation is given as:

- When the $p$-value is greater than or equal to the level of significance, there is no significant difference.

- When the $p$-value is lower than the level of significance, there is indeed a significant difference between the samples.

ANOVA was used to evaluate the influence of three levels of replacement rates of recycled aggregates in compressive strength and elasticity modulus of all concretes. It was also applied to the investigation of geometry changing influence in compressive strength, by using cubic and cylindrical specimens. 


\subsection{Prediction Formulations}

The parameters elasticity modulus and tensile strength were predicted using equations proposed by consulted standards NBR 6118:2014 [19], fib Model Code 2010 [20], Eurocode 2:2004 [21] and ACI 318:2014 [22]. Both parameters are predicted from concrete compressive strength. NBR 6118:2014 [19], fib Model Code [20] and ACI 318:2014 [22] use characteristic compressive strength $\left(\mathrm{f}_{\mathrm{ck}}\right)$ in the calculation, while Eurocode 2:2004 [21] uses measured compressive strength $\left(\mathrm{f}_{\mathrm{cm}}\right)$.

Deviation values prescribed by the standards were subtracted from $f_{c m}$ to determine $f_{c k}$. As each standard assumes a different deviation value, different values of $f_{c k}$ were determined. Standard deviation refers to concrete preparation conditions that assume laboratory conditions at the time of molding as well as how materials were separated. Table 3 lists the $f_{c k}$ calculated for all concretes considering each standard deviation.

Table 3. Characteristic compressive strength of concretes obtained according to standards.

\begin{tabular}{|c|c|c|c|c|c|}
\hline \multirow{2}{*}{ Concretes } & $\mathrm{f}_{\mathrm{cm}}{ }^{\mathrm{a}}$ & $f_{c k} b$ NBR 6118:2014 & $f_{c k}^{b}$ fib Model Code 2010 & $f_{\text {ck }}{ }^{b}$ Eurocode 2:2004 & $\mathrm{f}_{\mathrm{ck}}{ }^{\mathrm{b}} \mathrm{ACI}$ 318:2014 \\
\hline & (MPa) & (MPa) & (MPa) & (MPa) & (MPa) \\
\hline $\mathrm{C} 20$ & 36.05 & 29.45 & 28.05 & 28.05 & 27.78 \\
\hline C20-RCA20 & 31.99 & 25.39 & 23.99 & 23.99 & 23.72 \\
\hline C20-RCA50 & 23.01 & 16.41 & 15.01 & 15.01 & 14.74 \\
\hline C20-WPA30 & 35.50 & 28.90 & 27.50 & 27.50 & 27.23 \\
\hline C20-WPA50 & 35.57 & 28.97 & 27.57 & 27.57 & 27.30 \\
\hline $\mathrm{C} 40$ & 49.71 & 43.11 & 41.71 & 41.71 & 40.80 \\
\hline C40-RCA30 & 47.48 & 40.88 & 39.48 & 39.48 & 38.78 \\
\hline C40-RCA50 & 38.65 & 32.05 & 30.65 & 30.65 & 30.75 \\
\hline C40-WPA30 & 41.39 & 34.79 & 33.39 & 33.39 & 33.24 \\
\hline C40-WPA50 & 56.25 & 49.65 & 48.25 & 48.25 & 46.75 \\
\hline
\end{tabular}

Brazilian standard NBR 6118:2014 [19] considers a deviation of 6.60 MPa for concretes with strength ranging from $20 \mathrm{MPa}$ to $90 \mathrm{MPa}$ while Eurocode 2:2004 [21] considers a bigger deviation of 8.0 MPa for concretes with a range of strength between $12 \mathrm{MPa}$ and $90 \mathrm{MPa}$. American standard ACI 301:2010 [28] considers deviation of 8.274 MPa for concretes with strength ranging from $20 \mathrm{MPa}$ to $35 \mathrm{MPa}$, while, for concretes with strength above $35 \mathrm{MPa}$, Equation (1) is recommended. Fib Model Code 2010 [20] suggests an $8 \mathrm{MPa}$ deviation for concretes with compressive strength ranging from $12 \mathrm{MPa}$ to $120 \mathrm{MPa}$.

$$
f_{c}^{\prime}=\frac{\left(f_{c m}-4.826\right)}{1.10}
$$

\subsubsection{Elasticity Modulus Prediction}

Table 4 presents the prediction formulations to predict the elasticity modulus of concretes proposed by four different concrete designing standards [19-22]. In general, the elasticity modulus is obtained from concrete compressive strength, coarse aggregate nature and concrete density. The equations proposed by NBR 6118:2014 [19] and fib Model Code 2010 [20] are similar to each other, as both consider the parameter $\alpha_{\mathrm{E}}$, which depends on the nature of coarse aggregate.

Table 4. Elasticity modulus prediction equations proposed by standards.

\begin{tabular}{ccc}
\hline Standard & Tangent Modulus $\left(\mathbf{E}_{\mathbf{c i}}\right)$ & Secant Modulus $\left(\mathbf{E}_{\mathbf{c s}}\right)$ \\
\hline NBR 6118:2014 & $E_{c i}=\alpha_{E} 5600 \sqrt{f_{c k}}$ & $E_{c s}=\left(0.8+0.2\left(\frac{f_{c k}}{80}\right)\right) E_{c i}$ \\
fib Model Code 2010 & $E_{c i}=\alpha_{E} 21,000 \sqrt[3]{\frac{\left(f_{c k}+8\right)}{10}}$ & $E_{c}=\left(0.8+0.2\left(\frac{f_{c k}}{88}\right)\right) E_{c i}$ \\
Eurocode 2:2004 & $E_{c}=1.05 E_{c m}$ & $E_{c m}=22\left(\frac{f_{c m}}{10}\right)^{0.3}$ \\
ACI 318:2014 & $E_{c i}=4700 \sqrt{f_{c}^{\prime}}$ & - \\
\hline
\end{tabular}


The parameter related to coarse aggregate nature decreases or increases the predicted value of elasticity modulus: if the coarse aggregate is basalt or diabase then the value of elasticity modulus increases $20 \%$; if it is granite, gneiss or quartzite the value remains constant; if the coarse aggregate used is limestone, the elasticity modulus value reduces $10 \%$; and if it is sandstone coarse aggregate, it reduces $30 \%$. In this research, the natural coarse aggregates used to produce the concretes were basaltic, thus the value of $\alpha_{\mathrm{E}}$ is equal to 1.20 .

According to Brazilian standard NBR 8522:2017 [29], which determines the measured elasticity modulus, tangent modulus (or elasticity modulus) can be defined as the slope of the line tangent to the stress-strain curve between $\sigma_{\mathrm{a}}$ and $30 \%$ of $\mathrm{f}_{\mathrm{cm}}$, while secant modulus (or deformation modulus) is the slope of the stress-strain curve between $\sigma a$ and a stress within plastic strain zone (above $30 \%$ of $\mathrm{f}_{\mathrm{cm}}$ ).

Differently, fib Model Code 2010 [19] and Eurocode 2:2004 [21] set for the elasticity modulus a 40\% limit of $\mathrm{f}_{\mathrm{cm}}$, and, over this limit, a reduced modulus can be obtained (secant modulus). ACI 318:2014 [22] defines elasticity modulus as the slope of the line drawn from a stress of zero to compressive stress of $45 \%$ of $\mathrm{f}_{\mathrm{cm}}$, and it does not propose an equation to predict secant modulus.

\subsubsection{Tensile Strength Prediction}

Table 5 lists the prediction equations to predict the direct tensile strength $\left(\mathrm{f}_{\mathrm{ct}}\right)$ and splitting tensile strength $\left(f_{c t, s p}\right)$. NBR 6118:2014 [19], fib Model Code 2010 [20] and Eurocode 2:2004 [21] propose the same equation to calculate $\mathrm{f}_{\mathrm{ct}}$ while ACI 318:2014 [22] only presents an equation to predict $\mathrm{f}_{\mathrm{ct}, \mathrm{sp}}$.

Table 5. Tensile strength prediction equations proposed by standards.

\begin{tabular}{ccc}
\hline Standard & Direct Tensile Strength $\left.\mathbf{( f}_{\mathbf{c t}}\right)$ & Splitting or Indirect Tensile Strength $\left(\mathbf{f}_{\mathbf{c t}, \mathbf{s p}}\right)$ \\
\hline NBR 6118:2014 & $f_{c t m}=0.3\left(f_{c k}\right)^{\frac{2}{3}}$ & $f_{c t, s p}=f_{c t} / 0.90$ \\
fib Model Code 2010 & $f_{c t m}=0.3\left(f_{c k}\right)^{\frac{2}{3}}$ & $f_{c t m, s p}=f_{c t} / 1.00$ \\
Eurocode 2:2004 & $f_{c t m}=0.3\left(f_{c k}\right)^{\frac{2}{3}}$ & $f_{c t, s p}=f_{c t} / 0.90$ \\
ACI 318:2014 & - & $f_{c t}=0.56\left(f_{c k}\right)^{\frac{1}{2}}$ \\
\hline
\end{tabular}

The $\mathrm{f}_{\mathrm{ct}, \mathrm{sp}}$ is predicted in the same manner by Eurocode 2:2004 [21] and NBR 6118:2014 [19]; both standards consider a conversion factor of 0.90 to predict the splitting tensile strength out of direct tensile strength. Fib Model Code 2010 [20], on the other hand, considers a conversion factor of 1.00.

\section{Results}

The measured parameters were obtained by mechanical testing (i.e., compressive strength, tensile strength and elasticity modulus). Compressive strength was measured to predict the elasticity modulus and tensile strength values and to compare compressive strength using cylindrical and cubic specimens. Elasticity modulus and splitting tensile strength were measured to be compared with their predicted values.

\subsection{Measured Mechanical Results}

\subsubsection{Compressive Strength, $\mathrm{f}_{\mathrm{cm}}$}

Table 6 presents a tested 28-day average compressive strength $\left(\mathrm{f}_{\mathrm{cm}, \mathrm{cyl}}\right)$ molded in six cylindrical specimens $(100 \mathrm{~mm} \times 200 \mathrm{~mm})$. Individual values were discarded in respect of $6 \% \mathrm{COV}$ (coefficient of variation). 
Table 6. Tested results of concretes mechanical properties.

\begin{tabular}{|c|c|c|c|c|}
\hline \multirow{2}{*}{ Concretes } & $\mathrm{f}_{\mathrm{cm}, \mathrm{cyl}}$ & $\mathbf{f}_{\mathrm{cm}, \text { cube }}$ & $\mathbf{f}_{\mathrm{ctm}, \mathrm{sp}}$ & $\mathrm{E}_{\mathrm{cm}}$ \\
\hline & $(\mathrm{MPa})^{a}(\mathrm{COV})^{b}$ & $(\mathrm{MPa})^{a}(\mathrm{COV})^{b}$ & $(\mathrm{MPa})^{a}(\mathrm{COV})^{b}$ & $(\mathrm{GPa})^{a}(\mathrm{COV})^{b}$ \\
\hline $\mathrm{C} 20$ & $36.05(2.24 \%)$ & $42.09(5.48 \%)$ & $3.99(7.99 \%)$ & $36.16(5.25 \%)$ \\
\hline C20-RCA20 & $31.99(4.51 \%)$ & $36.53(5.14 \%)$ & $3.10(5.02 \%)$ & $40.82(3.59 \%)$ \\
\hline C20-RCA50 & $23.01(3.90 \%)$ & $31.68(6.86 \%)$ & $2.64(5.64 \%)$ & $32.01(4.79 \%)$ \\
\hline C20-WPA30 & $35.50(0.61 \%)$ & $54.32(4.62 \%)$ & $3.57(3.82 \%)$ & 41.59 (3.97\%) \\
\hline C20-WPA50 & $35.57(5.73 \%)$ & $39.70(5.63 \%)$ & $3.31(1.97 \%)$ & $43.07(5.80 \%)$ \\
\hline C40 & $49.71(3.40 \%)$ & $54.16(4.85 \%)$ & $5.14(4.98 \%)$ & $38.11(2.15 \%)$ \\
\hline C40-RCA30 & $47.48(5.72 \%)$ & $48.41(1.23 \%)$ & $4.29(5.86 \%)$ & $43.89(5.50 \%)$ \\
\hline C40-RCA50 & $38.65(15.47 \%)$ & $41.91(1.02 \%)$ & $4.63(2.19 \%)$ & $36.03(4.53 \%)$ \\
\hline C40-WPA30 & $41.39(10.44 \%)$ & $43.78(2.01 \%)$ & $4.34(4.72 \%)$ & $46.85(5.14 \%)$ \\
\hline C40-WPA50 & $56.25(7.30 \%)$ & $58.78(6.04 \%)$ & $4.50(0.57 \%)$ & $44.03(0.86 \%)$ \\
\hline
\end{tabular}

The individual specimen results of C40-RCA50 and C40-WPA30 were very dispersive, only three results of six specimens were considered for the average and the COV calculation.

The influence of recycled aggregates on concrete compressive strength was analyzed by using ANOVA single factor. ANOVA indicated which recycled aggregate concrete was significantly different from reference concrete (conventional concrete). Table 7 presents a one-way ANOVA analysis of the average compressive strength of $20 \mathrm{MPa}$ and $40 \mathrm{MPa}$ concretes. To determine if the compressive strength of a concrete with recycled aggregates differed from its reference concrete, ANOVA analysis was applied. Each row of Table 7 compares a pair of data. In these analysis results, $p$-value $<0.05$ indicates the compressive strengths have a significant difference. When $p$-value $\leq 0.05$, the test indicates the values are similar. Columns $\mathrm{F}$ and $\mathrm{f}$ are ANOVA auxiliary variables [30].

Table 7. ANOVA analysis on compressive strength of all concretes.

\begin{tabular}{|c|c|c|c|c|c|c|c|}
\hline \multirow{2}{*}{\multicolumn{2}{|c|}{ Concretes }} & \multirow{2}{*}{$\begin{array}{c}\text { Average } 1 \\
\text { (MPa) }\end{array}$} & \multirow{2}{*}{$\begin{array}{c}\text { Average } 2 \\
(\mathrm{MPa})\end{array}$} & \multirow{2}{*}{$\mathbf{F}$} & \multirow{2}{*}{$p$-Value } & \multirow{2}{*}{$\mathbf{F}$} & \multirow{2}{*}{ Average Difference } \\
\hline & & & & & & & \\
\hline $\mathrm{C} 20$ & C20-RCA30 & 36.05 & 31.99 & 12.68 & 0.0200 & 7.71 & 4.06 \\
\hline $\mathrm{C} 20$ & C20-RCA50 & 36.05 & 23.01 & 293.75 & 0.0001 & 7.71 & 13.03 \\
\hline $\mathrm{C} 20$ & C20-WPA30 & 36.05 & 35.50 & 1.43 & 0.3200 & 10.13 & 0.55 \\
\hline $\mathrm{C} 20$ & C20-WPA50 & 36.05 & 35.57 & 0.09 & 0.7800 & 7.71 & 0.47 \\
\hline $\mathrm{C} 40$ & C40-RCA30 & 49.71 & 47.48 & 1.10 & 0.3400 & 6.61 & 2.23 \\
\hline $\mathrm{C} 40$ & C40-RCA50 & 49.71 & 38.65 & 5.92 & 0.0900 & 10.13 & 11.06 \\
\hline $\mathrm{C} 40$ & C40-WPA30 & 49.71 & 41.39 & 6.18 & 0.0900 & 10.13 & 7.92 \\
\hline $\mathrm{C} 40$ & C40-WPA50 & 49.71 & 56.26 & 4.35 & 0.1700 & 18.51 & 6.54 \\
\hline
\end{tabular}

The test of C20 and C20-RCA30 indicated that their compressive strengths are statistically different ( $p$-value $=0.0200<0.05)$ the average compressive strength reduced $4.06 \mathrm{MPa}$ due to the addition of recycled aggregates. On the other hand, the test of C40 and C40-WPA50 indicated the compressive strength are not significantly different $(p$-value $=0.17)$. Even though the average difference is $6.54 \mathrm{MPa}$, the distribution of data is such that is $t$ is not possible to determine any influence from the addition of recycled aggregates.

Figure 8 illustrates the influence of RCA and WPA incorporation with replacement rates of $30 \%$ and $50 \%$. The $20 \mathrm{MPa}$ concretes are in dark gray columns while the $40 \mathrm{MPa}$ concretes are in light gray columns. A red line was drawn from the $\mathrm{f}_{\mathrm{cm}, \mathrm{cyl}}$ of reference concretes (C20 and $\left.\mathrm{C} 40\right)$ to compare with $\mathrm{f}_{\mathrm{cm}, \mathrm{cyl}}$ of recycled aggregate concretes (with RCA and WPA). 


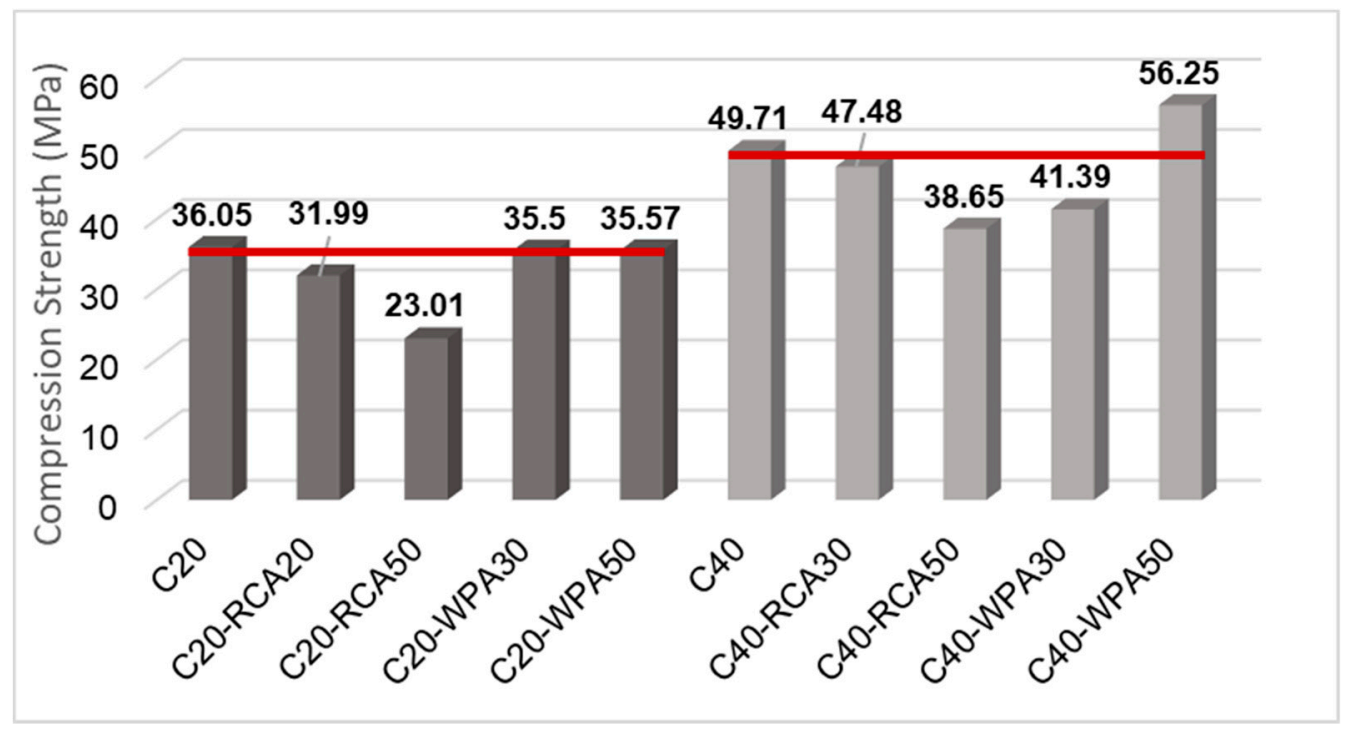

Figure 8. Compressive strength analysis of all concretes.

RCA concrete compressive strength was indicated by ANOVA analyses to differ significantly from reference compressive strength, while WPA concrete compressive strength was similar to reference compressive strength. Therefore, it was indicated that RCA incorporation negatively affects the strength of $20 \mathrm{MPa}$ concretes, while WPA is feasible to be used as aggregates.

Compressive strength decrease escalated when RCA replacement rate was increased because, by increasing the RCA replacement rate, compressive strengths of concretes were reduced due to RCA characteristics such as heterogeneity, porosity, high absorption and low strength [31]. At the age of 28 days, the compressive strength of C20-RCA30 decreased $11.25 \%$ while that of C20-RCA50 decreased $36.17 \%$.

The compressive strength of WPA concretes was equal to the conventional concrete compressive strength. It was assumed by Campos and Paulon [32] that this is due to the chemical and physical similarities between waste porcelain aggregates and natural aggregates. It was also state by Ferreira, et al. [33] that porcelains have high mechanical strength as a result of the presence of clay, feldspar and quartz, and therefore the mechanical results of WPA concretes are very satisfactory. For $40 \mathrm{MPa}$ concretes, neither of the recycled aggregates used in this research (RCA and WPA) affected substantially the compressive strength, as indicated by ANOVA analysis.

\subsubsection{Compressive Cubic Strength, $\mathrm{f}_{\mathrm{cm} \text {, cubic }}$}

The average compressive cubic strength $\left(\mathrm{f}_{\mathrm{cm}, \text { cube }}\right)$ was measured from six cubic specimens of $100 \mathrm{~mm}$. Table 6 presents the average compressive cubic strength in comparison to average compressive cylindrical strength. Correspondingly, individual values were discarded and $6 \%$ of COV (coefficient of variation) was respected.

It is understood that the size and shape of specimens vary according to which standard is adopted and which types of materials are used at the time of testing. Commonly, European countries use cubic specimens to determine compressive strength, while in Brazil, USA and other countries cylindrical specimens with 2.00 height/diameter ratio are often used. Some countries use both cubic and cylindrical specimens $[34,35]$.

According to Watanabe, et al. [36], the stress-strain curves of concrete strongly depend on the aspect ratio of the concrete specimen. Specimen parameters such as size, geometry and humidity conditions generally affect the results obtained in mechanical tests [37]. It was appointed by Kaish et al. [38] that these effects are deeply known in tensile strength results while in compressive strength the effects of size and shape of concrete specimens are not widely investigated. 
Therefore, this study aimed to evaluate the compressive strength behavior of concretes cast in cylindrical and cubic specimens. An ANOVA analysis was performed to validate the difference between these two strengths. Table 8 presents an ANOVA analysis comparing compressive strength cast in cylindrical specimens $\left(\mathrm{f}_{\mathrm{cm}, \mathrm{cyl}}\right)$ and cast in cubic specimens $\left(\mathrm{f}_{\mathrm{cm}, \mathrm{cube}}\right)$ of all concretes.

Table 8. ANOVA analysis on compressive strength of concretes.

\begin{tabular}{ccccccc}
\hline \multirow{2}{*}{ Concretes } & $\mathbf{f}_{\mathbf{c m}, \mathbf{c y l}}$ & $\mathbf{f}_{\mathbf{c m}, \mathbf{c u b e}}$ & & & & \\
\cline { 2 - 4 } & $\mathbf{( M P a})$ & $\mathbf{( M P a})$ & $\mathbf{F}$ & $\boldsymbol{p}$-Value & $\mathbf{F}$ & Average Difference \\
\hline C20 & 36.05 & 42.09 & 11.74 & 0.0266 & 7.71 & 6.05 \\
C20-RCA30 & 31.99 & 36.53 & 13.26 & 0.0149 & 6.61 & 4.54 \\
C20-RCA50 & 23.02 & 31.68 & 55.36 & 0.0001 & 5.32 & 8.67 \\
C20-WPA30 & 35.50 & 54.32 & 159.84 & 0.0001 & 6.61 & 18.82 \\
C20-WPA50 & 35.57 & 39.71 & 6.53 & 0.0509 & 6.61 & 4.13 \\
C40 & 49.71 & 54.16 & 4.51 & 0.1000 & 7.71 & 4.45 \\
C40-RCA30 & 47.48 & 48.41 & 0.32 & 0.5900 & 5.99 & 0.93 \\
C40-RCA50 & 38.65 & 41.91 & 0.53 & 0.5200 & 10.13 & 3.26 \\
C40-WPA30 & 41.39 & 43.78 & 1.23 & 0.3200 & 6.61 & 2.39 \\
C40-WPA50 & 56.26 & 58.78 & 0.55 & 0.5100 & 10.13 & 2.53 \\
\hline
\end{tabular}

Figure 9 illustrates the difference between $\mathrm{f}_{\mathrm{cm}}$ and $\mathrm{f}_{\mathrm{cm} \text {,cube }}$. Mucciacia et al. [37] explained that the height/diameter ratio is responsible for this difference: the higher is the height/diameter ratio, the lower is the strength. The height/diameter ratio used in this research was 1.00 for cubic specimens and 2.00 for cylindrical specimens.

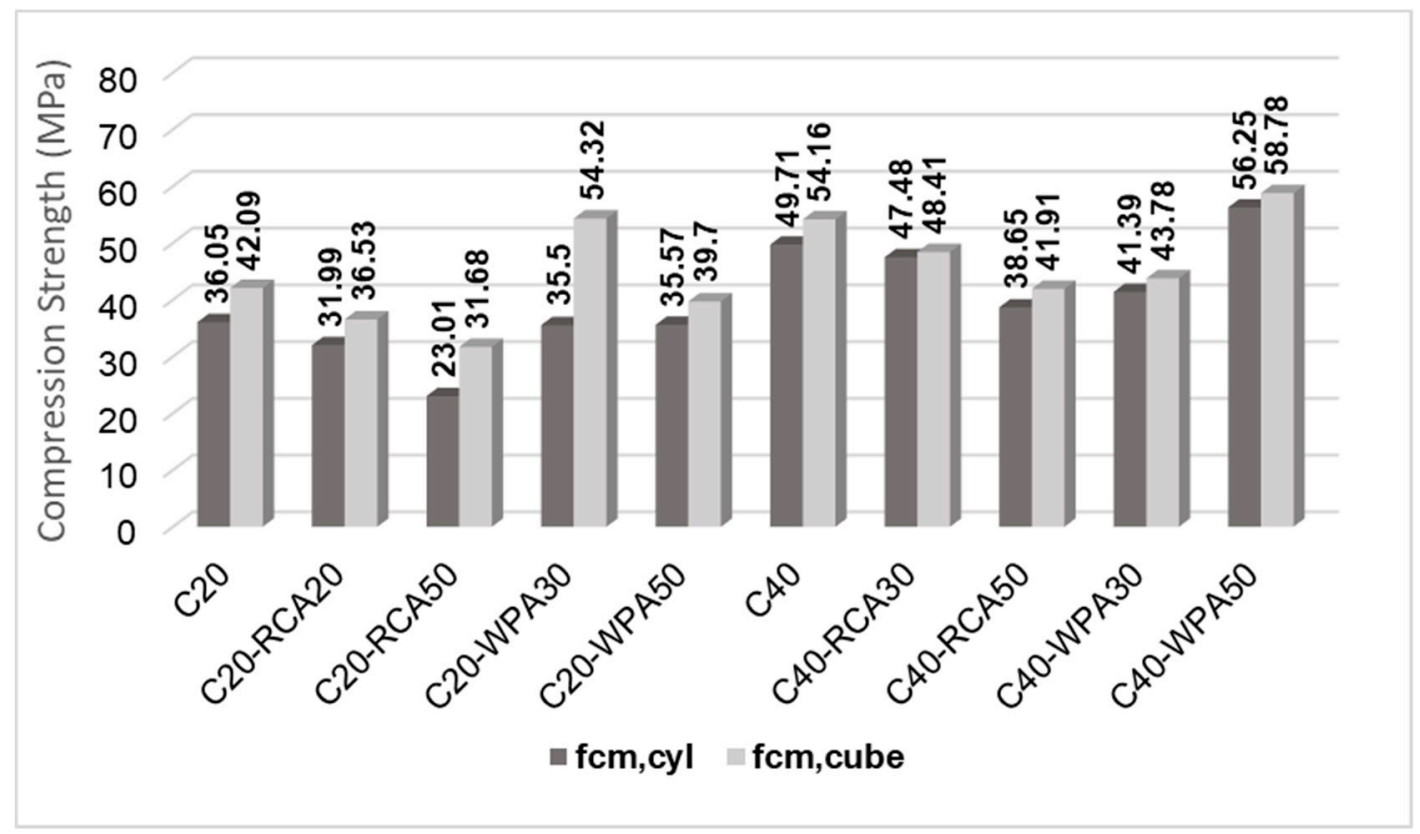

Figure 9. Cubic and cylindrical compressive strength comparative analysis of all concretes.

For $20 \mathrm{MPa}$ concretes, cubic strengths were higher than cylindrical strengths (with an increase ranging from $11.61 \%$ to $53.02 \%$ ). All results were validated by an ANOVA analysis, which indicated that the type of specimen significantly influenced the strength result.

It was said by Sinaie, et al. [39] that specimens with a lower height/diameter ratio normally lead to higher strengths, and Neville [40] indicated that, when the height/diameter ratio decreases, stresses and peak deformations usually also reduce, leading to greater strengths. It was explained by Gyurkó 
and Nemes [41] that a possible reason would be the effect of enclosing caused by the press plates all over the cube's height, but, in cylinders, it does not reach some part of the height.

Unlike $20 \mathrm{MPa}$ concretes, $40 \mathrm{MPa}$ concretes did not have a significant difference between cylindrical and cubic strengths. The type of geometry did not substantially affect the $40 \mathrm{MPa}$ concrete strength results, except for C40-WPA30, which indicated a significant difference. According to Gyurkó and Nemes [41], the relationship between the cylinder and cube strengths increases greatly with strength classification increasing. The Soares at al. [42] also found in their investigation that the effect of specimen geometry is more significant in low strength class concrete (C20/25).

Table 9 shows the relationship between the cylindrical and cubic strength of concretes, and it was observed that the cylindrical/cubic strength ratio of $40 \mathrm{MPa}$ concretes is greater than that of $20 \mathrm{MPa}$ concretes.

Table 9. Compressive cylinder strength and compressive cube strength ratio of concretes.

\begin{tabular}{|c|c|c|c|c|c|c|c|c|c|c|}
\hline Concretes & $\mathrm{C} 20$ & C20-ARC30 & C20-ARC50 & C20-ARP30 & C20-ARP50 & $\mathrm{C} 40$ & C40-ARC30 & C40-ARC50 & C40-ARP30 & C40-ARP50 \\
\hline $\mathrm{f}_{\mathrm{cm}, \mathrm{cyl}}(\mathrm{MPa})$ & 36.05 & 31.99 & 23.01 & 35.5 & 35.57 & 49.71 & 47.48 & 38.65 & 41.39 & 56.25 \\
\hline $\mathrm{f}_{\mathrm{cm}, \mathrm{cyl}} / \mathrm{f}_{\mathrm{cm}, \text { cube }}$ & 0.86 & 0.88 & 0.73 & 0.65 & 0.90 & 0.92 & 0.98 & 0.92 & 0.95 & 0.96 \\
\hline
\end{tabular}

\subsubsection{Splitting Tensile Strength, $\mathrm{f}_{\mathrm{ctm}, \mathrm{sp}}$}

Average splitting tensile strength was determined by measuring six cylindrical specimens $(200 \mathrm{~mm} \times 100 \mathrm{~mm})$ at the age of 28 days. Table 6 presents all concretes values of splitting tensile strength. Individual values were discarded if they favored the increase of COV (coefficient of variation) above $6 \%$.

Compressive strength is the main mechanical property of concrete used by many engineers for designing and inspecting concrete structures. Splitting tensile strength and flexural tensile strength, on the other hand, are not so commonly used; normally they are $10 \%$ and $15 \%$ of compressive strength, respectively [35]. As shown in Table 10, the splitting tensile strength of the concretes is from $8 \%$ to $12 \%$ of the compressive strength.

Table 10. Measured splitting tensile strength and compressive strength ratio of concretes.

\begin{tabular}{ccccccccccc}
\hline Concretes & C20 & C20-ARC30 & C20-ARC50 & C20-ARP30 & C20-ARP50 & C40 & C40-ARC30 & C40-ARC50 & C40-ARP30 & C40-ARP50 \\
\hline $\mathrm{f}_{\mathrm{cm}, \mathrm{cyl}}(\mathrm{MPa})$ & 36.05 & 31.99 & 23.01 & 35.5 & 35.57 & 49.71 & 47.48 & 38.65 & 41.39 & 56.25 \\
$\mathrm{f}_{\mathrm{ctm}, \mathrm{sp}}(\mathrm{MPa})$ & 3.99 & 3.10 & 2.64 & 3.57 & 3.31 & 5.14 & 4.29 & 4.63 & 4.34 & 4.5 \\
$\mathrm{f}_{\mathrm{ctm}, \mathrm{sp}} / \mathrm{f}_{\mathrm{cm}, \mathrm{cyl}}$ & $11 \%$ & $10 \%$ & $11 \%$ & $10 \%$ & $9 \%$ & $10 \%$ & $9 \%$ & $12 \%$ & $10 \%$ & $8 \%$ \\
\hline
\end{tabular}

It was also state by Mehta and Monteiro [35] that compressive and tensile strength are closely related: as compressive strength increases, tensile strength also increases, but at a decreasing rate. Thus, the higher is the compressive strength, the lower is the tensile/compressive strength ratio.

This statement is proven by analyzing the results in Table 10, which shows that the concrete with the highest strength (C40-WPA50) is the one with the lowest tensile/compressive strength ratio, while the concrete with the lowest strength (C20-RCA50) has the lowest tensile/compressive strength ratio.

\subsubsection{Elasticity Modulus $\mathrm{E}_{\mathrm{cm}}$}

Six cylindrical specimens $(100 \mathrm{~mm} \times 200 \mathrm{~mm})$ were tested at 28 days to obtain an average elasticity modulus. The test followed NBR 8522:2017 [29], thus it was necessary to discard some individual values when effective strength $\left(\mathrm{f}_{\mathrm{c}, \mathrm{ef}}\right)$ was different from concrete compressive strength by $\pm 20 \%$. COV (coefficient of variation) of $6 \%$ was considered. Table 6 displays the results of the average elasticity modulus.

ANOVA single factor was used to investigate which recycled aggregate (RCA or WPA) and in what proportions significantly affected the elasticity modulus. Reference concrete elasticity moduli were individually compared to those of recycled aggregate concretes. Table 11 exhibits the ANOVA analysis of concretes elasticity modulus. 
Table 11. ANOVA analysis on elasticity modulus of concretes.

\begin{tabular}{|c|c|c|c|c|c|c|c|}
\hline \multirow{2}{*}{\multicolumn{2}{|c|}{ Concretes }} & \multirow{2}{*}{$\begin{array}{c}\text { Average } 1 \\
\text { (MPa) }\end{array}$} & \multirow{2}{*}{$\begin{array}{c}\text { Average } 2 \\
(\mathrm{MPa})\end{array}$} & \multirow{2}{*}{$\mathbf{F}$} & \multirow{2}{*}{$p$-Value } & \multirow{2}{*}{$\mathbf{F}$} & \multirow{2}{*}{ Average Difference } \\
\hline & & & & & & & \\
\hline $\mathrm{C} 20$ & C20-RCA30 & 36.16 & 40.82 & 20 & 0.002 & 5.12 & 4.66 \\
\hline $\mathrm{C} 20$ & C20-RCA50 & 36.16 & 32.01 & 15.38 & 0.004 & 5.12 & 4.15 \\
\hline $\mathrm{C} 20$ & C20-WPA30 & 36.16 & 41.59 & 21.54 & 0.002 & 5.32 & 5.42 \\
\hline $\mathrm{C} 20$ & C20-WPA50 & 36.16 & 43.07 & 27.19 & 0.001 & 5.12 & 6.9 \\
\hline $\mathrm{C} 40$ & C40-RCA30 & 38.11 & 43.89 & 9.79 & 0.052 & 10.13 & 5.78 \\
\hline $\mathrm{C} 40$ & C40-RCA50 & 38.11 & 36.03 & 2.6 & 0.248 & 18.51 & 2.09 \\
\hline $\mathrm{C} 40$ & C40-WPA30 & 38.11 & 46.85 & 23.18 & 0.003 & 5.99 & 8.74 \\
\hline $\mathrm{C} 40$ & C40-WPA50 & 38.11 & 44.03 & 85.82 & 0.012 & 18.51 & 5.92 \\
\hline
\end{tabular}

Figure 10 illustrates a comparison between elasticity modulus of conventional concretes and elasticity modulus of recycled aggregate concretes. The $20 \mathrm{MPa}$ concretes are in dark gray columns, while the $40 \mathrm{MPa}$ concretes are in light gray columns. A red line was drawn from the elasticity modulus of conventional concretes (C20 and C40) to compare with the elasticity modulus of RCA and WPA concretes.

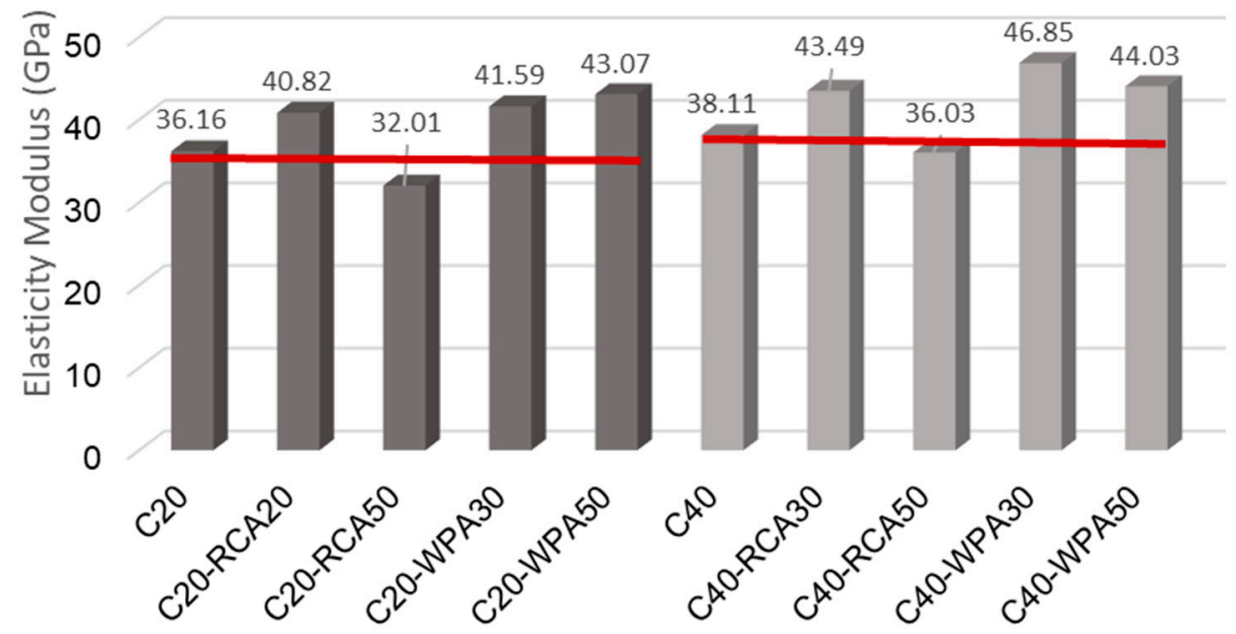

Figure 10. Elasticity modulus analysis of all concretes.

Through ANOVA analysis, it was possible to establish that both recycled aggregates (RCA and WPA) affect the elasticity modulus because concretes with recycled aggregates indicated significant difference when compared to reference concretes, except for C40-RCA50, for which, according to ANOVA analysis, the average elasticity modulus is similar to the average elasticity modulus of conventional concretes.

Recycled aggregates typically reduce the value of concretes elasticity modulus. It was shown by Manzi, et al. [43] that, as RCA replacement rate increases, the modulus of elasticity decreases, because concrete elasticity modulus is influenced by porosity presented in each of the concretes parts.

However, in this study, the concretes with $30 \%$ of RCA (C20-RCA30 and C40-RCA30) had a respective increase of $5.84 \%$ and $4.87 \%$ in the elasticity modulus, while the concrete with $50 \%$ of RCA had a reduction. The Milhomen et al. [44] also observed an increase in the modulus of elasticity of self-consolidating concrete produced with both recycled fine and coarse aggregates. The authors believed that the improvement was due to better adhesion of cement paste and mortar to the particles of recycled aggregates.

Regarding the use of waste porcelain aggregates (WPA), some authors verified that the characteristics of high rigidity and high mechanical strength of porcelain benefit concrete mechanical 
properties [32,45]. WPA concrete tended to increase the elasticity modulus of $20 \mathrm{MPa}$ and $40 \mathrm{MPa}$ concretes, with both replacement rates (30\% and 50\%), in the range of $15.02-22.93 \%$.

It is believed that the cause of this increase is due to the rough surface of the porcelain aggregates (non-polished surface). When De Argollo Ferrão, et al. [45] analyzed the aggregate-paste transition zone with Scanning Electron Microscopy (SEM), they observed that the present roughness in porcelain without polishing allows the paste to adhere easily, thus benefiting the modulus of elasticity.

\subsection{Predicted Values}

\subsubsection{Predicted Tensile Strength}

Table 12 lists the values of direct tensile strength $\left(\mathrm{f}_{\mathrm{ct}}\right)$ and splitting tensile strength values $\left(\mathrm{f}_{\mathrm{ct}, \mathrm{sp}}\right)$ calculated by standards NBR6118:2014 [19], fib Model Code 2010 [20], Eurocode 2:2004 [21] and ACI318:2014 [22] in comparison to measured results of splitting tensile strength $\left(\mathrm{f}_{\mathrm{ctm}, \mathrm{sp}}\right)$.

Table 12. Predicted tensile strength of concretes according to standards in comparison to measured results.

\begin{tabular}{|c|c|c|c|c|c|c|c|c|c|}
\hline \multirow{2}{*}{ Concretes } & \multirow{2}{*}{$\begin{array}{c}\text { Measured Results } \\
\text { NBR 7222:2011 } \\
\mathrm{f}_{\mathrm{ctm}, \mathrm{sp}}(\mathrm{MPa})\end{array}$} & \multicolumn{8}{|c|}{ Predicted Values } \\
\hline & & $\mathrm{f}_{\mathrm{ct}}(\mathrm{MPa})$ & $\mathrm{f}_{\mathrm{ct}, \mathrm{sp}}(\mathrm{MPa})$ & $\mathrm{f}_{\mathrm{ct}}(\mathrm{MPa})$ & $\mathrm{f}_{\mathrm{ct}, \mathrm{sp}}(\mathrm{MPa})$ & $\mathrm{f}_{\mathrm{ct}}(\mathrm{MPa})$ & $\mathrm{f}_{\mathrm{ct}, \mathrm{sp}}(\mathrm{MPa})$ & $\mathrm{f}_{\mathrm{ct}}(\mathrm{MPa})$ & $\mathrm{f}_{\mathrm{ct}, \mathrm{sp}}(\mathrm{MPa})$ \\
\hline C20-ARC30 & 3.10 & 2.59 & 2.88 & 2.50 & 2.77 & 2.50 & 2.50 & ND & 3.17 \\
\hline C20-ARC50 & 2.64 & 1.94 & 2.15 & 1.83 & 2.03 & 1.83 & 1.83 & ND & 2.69 \\
\hline C20-ARP30 & 3.57 & 2.83 & 3.14 & 2.73 & 3.04 & 2.73 & 2.73 & ND & 3.34 \\
\hline C40-ARC30 & 4.29 & 3.56 & 3.96 & 3.48 & 3.86 & 3.48 & 3.48 & ND & 3.86 \\
\hline C40-ARC50 & 4.63 & 3.03 & 3.36 & 2.94 & 3.26 & 2.94 & 2.94 & ND & 3.48 \\
\hline C40-ARP30 & 4.34 & 3.20 & 3.55 & 3.11 & 3.46 & 3.11 & 3.11 & ND & 3.60 \\
\hline C40-ARP50 & 4.50 & 4.05 & 4.50 & 3.98 & 4.42 & 3.98 & 3.98 & ND & 4.20 \\
\hline
\end{tabular}

Different values of tensile strength were obtained through different standards calculations because they adopt different coefficients and deviation values. In general, the predicted values of splitting tensile strength of all concretes calculated by Eurocode 2:2004 [21] were lower than the rest of the values predicted by other standards.

For all concretes, values of splitting tensile strength predicted by ACI 318:2014 [22] were superior to values predicted by other standards, followed by values calculated by NBR 6118:2014 [19] and fib Model Code 2010 [20].

The $20 \mathrm{MPa}$ concretes resulted in lower predicted splitting tensile strength when compared to the $40 \mathrm{MPa}$ concretes, proving that the value of splitting tensile strength depends on the variation of concrete compressive strength.

As Brazilian standard NBR 6118:2014 [19] and fib Model Code 2010 [20] consider a correction factor of 0.90 , values of predicted direct tensile strength $\left(f_{\mathrm{ct}}\right)$ were lower than predicted splitting tensile strength $\left(f_{c t, s p}\right)$. Eurocode 2:2004 [21], on the other hand, considers a correction factor of 1.00, hence $f_{c t}$ values were the same as $f_{c t, s p}$ values.

The ratio between measured splitting tensile strength and measured compressive strength $\left(\mathrm{f}_{\mathrm{ctm}, \mathrm{sp}} / \mathrm{f}_{\mathrm{cm}, \mathrm{cyl}}\right)$ was calculated. The ratio between predicted splitting tensile strength and characteristic compressive strength $\left(\mathrm{f}_{\mathrm{ct}, \mathrm{sp}} / \mathrm{f}_{\mathrm{ck}}\right)$ was also determined. Table 13 lists the measured and predicted ratios of these two parameters for all concretes. 
Table 13. Predicted splitting tensile and compressive strength ratio of concretes.

\begin{tabular}{|c|c|c|c|c|c|}
\hline \multirow{3}{*}{ Concretes } & \multirow{3}{*}{$\begin{array}{c}\text { Measured Results } \\
\mathbf{f}_{\mathrm{ctm}, \mathrm{sp}} / \mathrm{f}_{\mathrm{cm}, \mathrm{cyl}}\end{array}$} & \multicolumn{4}{|c|}{ Predicted Values } \\
\hline & & NBR 6118:2014 & fib Model Code 2010 & Eurocode 2:2004 & ACI 318:2014 \\
\hline & & $\mathbf{f}_{\mathrm{ct}, \mathrm{sp}} / \mathbf{f}_{\mathrm{ck}}$ & $\mathbf{f}_{\mathrm{ct}, \mathrm{sp}} / \mathbf{f}_{\mathrm{ck}}$ & $\mathbf{f}_{\mathrm{ct}, \mathrm{sp}} / \mathbf{f}_{\mathrm{ck}}$ & $\mathbf{f}_{\mathrm{ct}, \mathrm{sp}} / \mathbf{f}_{\mathrm{ck}}$ \\
\hline C20 & $11 \%$ & $11 \%$ & $11 \%$ & $10 \%$ & $12 \%$ \\
\hline C20-ARC30 & $10 \%$ & $11 \%$ & $12 \%$ & $10 \%$ & $13 \%$ \\
\hline C20-ARC50 & $11 \%$ & $13 \%$ & $14 \%$ & $12 \%$ & $18 \%$ \\
\hline C20-ARP30 & $10 \%$ & $11 \%$ & $11 \%$ & $10 \%$ & $12 \%$ \\
\hline C20-ARP50 & $9 \%$ & $11 \%$ & $11 \%$ & $10 \%$ & $12 \%$ \\
\hline $\mathrm{C} 40$ & $10 \%$ & $10 \%$ & $10 \%$ & $9 \%$ & $10 \%$ \\
\hline C40-ARC30 & $9 \%$ & $10 \%$ & $10 \%$ & $9 \%$ & $10 \%$ \\
\hline C40-ARC50 & $12 \%$ & $10 \%$ & $11 \%$ & $10 \%$ & $11 \%$ \\
\hline C40-ARP30 & $10 \%$ & $10 \%$ & $10 \%$ & $9 \%$ & $11 \%$ \\
\hline C40-ARP50 & $8 \%$ & $9 \%$ & $9 \%$ & $8 \%$ & $9 \%$ \\
\hline
\end{tabular}

\subsubsection{Predicted Elasticity Modulus}

Table 14 brings together the predicted values of elasticity modulus for $20 \mathrm{MPa}$ and $40 \mathrm{MPa}$ concretes with equations proposed by NBR 6118:2014 [19], fib Model Code 2010 [20], Eurocode 2:2004 [21] and ACI318:2014 [22].

Table 14. Predicted elasticity modulus of concretes according to standards in comparison to measured results.

\begin{tabular}{|c|c|c|c|c|c|}
\hline \multirow[b]{2}{*}{ Concretes } & \multirow{2}{*}{$\begin{array}{c}\text { Measured Results } \\
\text { NBR 8522:2017 } \mathrm{E}_{\mathrm{cm}} \\
(\mathrm{GPa})\end{array}$} & \multicolumn{4}{|c|}{ Predicted Values } \\
\hline & & $\begin{array}{c}\text { NBR 6118:2014 } \mathrm{E}_{\mathrm{ci}} \\
(\mathrm{GPa})\end{array}$ & $\begin{array}{l}\text { Fib Model Code } \\
2010 \mathrm{E}_{\mathrm{ci}}(\mathrm{GPa})\end{array}$ & $\begin{array}{l}\text { Eurocode 2:2004 } \mathrm{E}_{\mathrm{ci}} \\
\quad(\mathrm{GPa})\end{array}$ & $\begin{array}{c}\text { ACI 318:2014 } \mathrm{E}_{\mathrm{c}} \\
\text { (GPa) }\end{array}$ \\
\hline C20-ARC30 & 40.82 & 33.86 & 38.02 & 32.74 & 22.89 \\
\hline C20-ARC50 & 32.01 & 27.22 & 34.06 & 29.66 & 18.04 \\
\hline C20-ARP30 & 41.59 & 36.13 & 39.36 & 33.78 & 24.52 \\
\hline C40-ARC30 & 43.89 & 42.97 & 43.36 & 36.86 & 29.27 \\
\hline C40-ARC50 & 36.03 & 38.04 & 40.49 & 34.65 & 26.06 \\
\hline C40-ARP30 & 46.85 & 39.64 & 41.42 & 35.37 & 27.1 \\
\hline C40-ARP50 & 44.03 & 47.35 & 45.88 & 38.78 & 32.14 \\
\hline
\end{tabular}

The predicted values of elasticity modulus resulted in different values when calculated by the different equations proposed by each standard because they consider different coefficients and deviation values. In general, the predicted elasticity modulus of all concrete (20 MPa and $40 \mathrm{MPa}$ concretes) calculated by ACI 318:2014 [22] were lower than those predicted by other standards.

For 20 MPa concretes, the elasticity moduli predicted by fib Model Code 2010 [20] were superior to those predicted by other standards and were followed by the moduli calculated by NBR 6118:2014 [19] and Eurocode 2:2004 [21]. Except for C20-RCA50, the descending order of predicted moduli were calculated by: fib Model Code 2010 [20], Eurocode 2:2004 [21], NBR 6118:2014 [19] and ACI 318:2014 [22].

For $40 \mathrm{MPa}$ concretes, the predicted elasticity moduli calculated by NBR 6118:2014 [19] were similar to the modulus predicted by fib Model Code 2010 [20], although the moduli with the highest occurrence of great values were those calculated by fib Model Code 2010 [20].

The $20 \mathrm{MPa}$ concretes resulted in lower predicted elasticity modulus when compared to the $40 \mathrm{MPa}$ concretes, proving that the value of elasticity modulus depends on the variation of concrete compressive strength.

The consulted standards do not indicate a value which represents the nature of recycled aggregate of concrete (RCA) and porcelain (WPA); therefore, the parameter depending on the nature of coarse aggregate $\left(\alpha_{\mathrm{E}}=1.20\right)$ used was the same for all calculations, even though the predicted modulus of elasticity was similar to measured compressive strength behavior. 


\subsection{Comparison between Predicted Values and Measured Mechanical Results}

\subsubsection{Predicted vs. Measured tensile strength}

Figure 11 illustrates the difference between measured and predicted splitting tensile strength of all concretes. Measured splitting tensile strength $\left(\mathrm{f}_{\mathrm{ctm}, \mathrm{sp}}\right)$ are indicated in green columns while predicted splitting tensile strength $\left(\mathrm{f}_{\mathrm{ct}, \mathrm{sp}}\right)$ calculated by NBR6118:2014 (gray) [19], fib Model Code 2010 (blue) [20], Eurocode 2:2004 (yellow) [21] and ACI 318:2014 (orange) [22] are shown in colored columns.

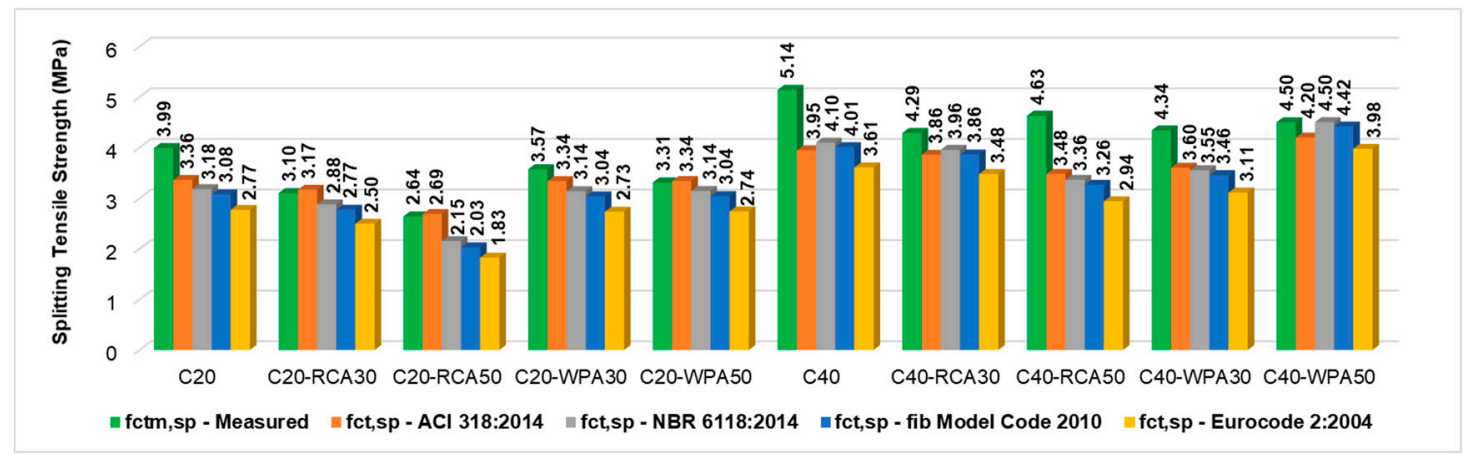

Figure 11. Comparison of measured and predicted splitting tensile strength considering standards.

For $20 \mathrm{MPa}$ concretes, most measured splitting tensile strength were lower than predicted values calculated by ACI 318:2014 [22], indicating a lack of safety by the American standard. On the contrary, for $40 \mathrm{MPa}$ concretes, all measured splitting tensile strengths were greater than splitting tensile strengths predicted by all the standards.

\subsubsection{Predicted vs. Measured Elasticity Modulus}

The comparative analysis of measured elasticity modulus and predicted elasticity modulus calculated by standards is illustrated in Figure 12. Measured elasticity modulus is indicated in black columns while predicted elasticity modulus are indicated in different colored columns in the figure.

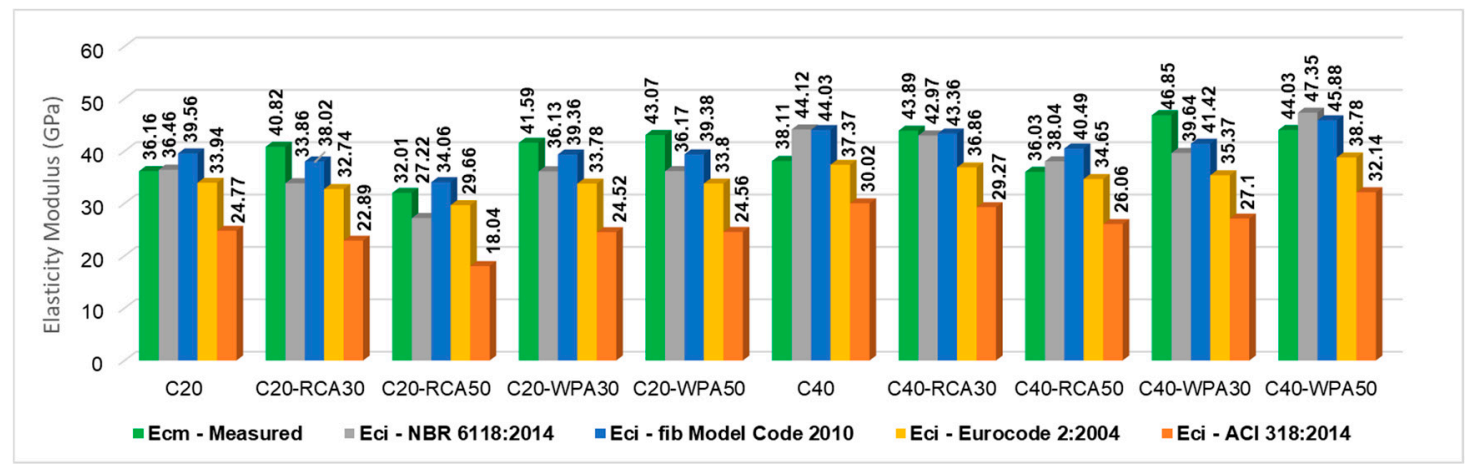

Figure 12. Comparison of measured and predicted elasticity modulus of concretes considering standards.

The difference between measured and predicted elasticity modulus is more alarming when elasticity modulus was calculated by fib Model Code 2010 [20] and NBR 6118:2014 [19]. Both standards did not indicate the safety of structure serviceability. Safety is obtained when the measured modulus is equal to or greater than the predicted modulus. For conventional concretes (C20 and C40), the measured elasticity modulus was lower than modulus predicted by fib Model Code 2010 [20] (in 8.59\% and $13.45 \%$, respectively) and by NBR 6118:2014 [19] (in 0.82\% and 13.62\%, respectively).

ACI 318:2014 [22] and Eurocode 2:2004 [21], on the other hand, indicate safety for conventional concretes because measured elasticity modulus was superior to the predicted modulus. The measured 
elasticity moduli of C20 and C40 were $6.54 \%$ and $1.98 \%$ higher than the moduli predicted by Eurocode 2:2004 [21] and 45.98\% and 26.95\% higher than the moduli predicted by ACI 318:2014 [22].

For concretes with 50\% of RCA, the measured elasticity modulus was inferior to the modulus predicted by fib Model Code 2010 [20]. The elasticity modulus of C20-RCA50 was 6.02\% lower than the modulus predicted by fib Model Code 2010 [20], while that of C40-RCA50 was 11.01\% lower than the modulus predicted by fib Model Code 2010 [20]. For concretes with $30 \%$ ARC, the measured modulus was superior to the predicted modulus. The measured elasticity modulus of C20-RCA30 was 7.36\% larger than the fib Model Code 2010 [20] modulus, 20.55\% larger than the NBR 6118:2014 [19] modulus, 24.68\% larger than the Eurocode 2:2004 [21] modulus and 78.33\% larger than the ACI 318:2014 [22] modulus. The measured elasticity modulus of C40-RCA30 is larger than modulus predicted by fib Model Code 2010 [20], NBR 6118:2014 [19], Eurocode 2:2004 [21] and ACI 318:2014 [22] by 1.22\%, 2.14\%, $19.07 \%$ and $49.95 \%$, respectively.

The measured elasticity modulus of concretes with $30 \%$ and $50 \%$ of WPA were superior to the predicted modulus, except for C40-WPA50 with lower measured modulus than modulus predicted by fib Model Code 2010 [20] (4.03\%) and by NBR 6118:2014 [19] (at 7.01\%).

Another analysis was performed to calculate the modulus of elasticity considering different parameters related to aggregates nature $\left(\alpha_{\mathrm{E}}\right)$, prescribed by Brazilian standard NBR 6118:2014 [19]. The parameter $\alpha_{\mathrm{E}}=1.20$ represents aggregates of basalt or diabasium, $\alpha_{\mathrm{E}}=1.00$ represents granite aggregate or gneiss, $\alpha_{\mathrm{E}}=0.90$ considers limestone aggregate and $\alpha_{\mathrm{E}}=0.70$ indicates sandstone aggregate. For this study, $\alpha_{\mathrm{E}}=1.20$ was initially considered in the calculations due to the use of basaltic coarse aggregates.

Considering $\alpha_{\mathrm{E}}=1.20$, the concretes which resulted in a measured elasticity modulus lower than the predicted modulus were C20, C40, C40-RCA50 and C40-WPA50. Therefore, the elasticity modulus was calculated considering $\alpha_{\mathrm{E}}=1.00$ (granite or gneiss) to investigate whether the measured elasticity modulus of these concretes would be above or below the values of modulus considering $\alpha_{\mathrm{E}}=1.00$. Figure 13 shows the measured elasticity modulus in comparison to predicted modulus considering different parameters $\left(\alpha_{\mathrm{E}}\right)$.

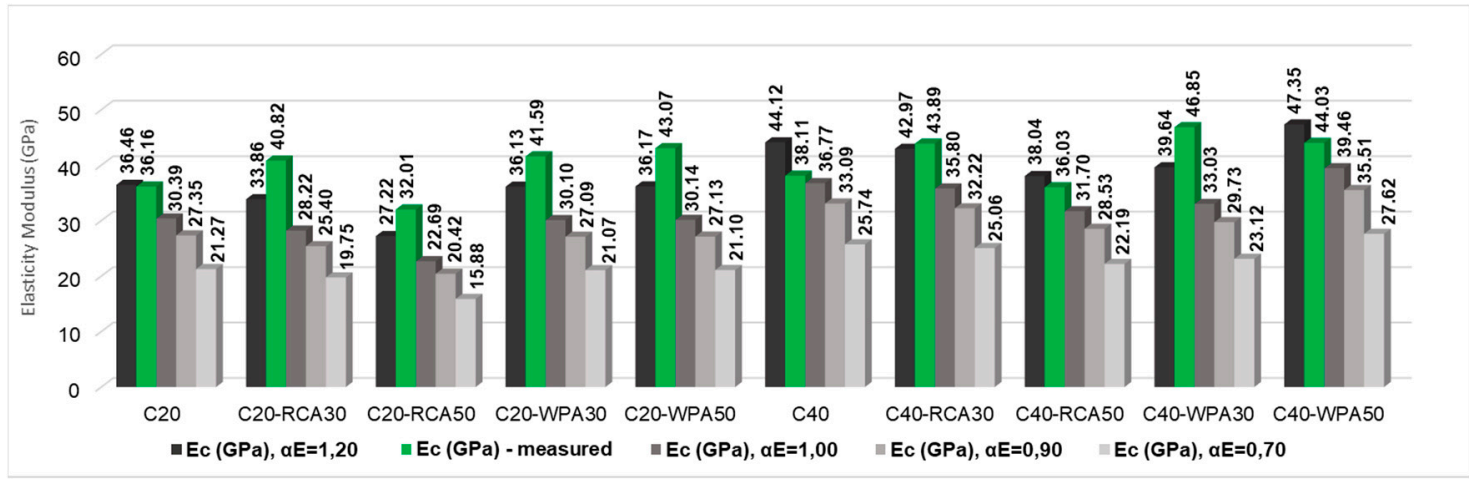

Figure 13. Comparison of measured elasticity modulus and elasticity modulus predicted with different values of $\alpha_{\mathrm{E}}$.

Measured elasticity modulus (green columns) of C20, C40, C40-RCA50 and C40-WPA50 when predicted considering $\alpha_{\mathrm{E}}=1.00$ (granite) were superior to the predicted modulus.

\section{Conclusions}

In the literature, it is acknowledged that conventional concrete has a complex structure. Knowing all the influence factors which affect concrete mechanical properties is recognized to be an arduous task. The insertion of recycled aggregates in concrete structure makes the task even more complex because of the great variability these aggregates causes in concrete structure behavior. 
Most research on the usage of recycled aggregates is concerned with the influence of these aggregates on compressive strength. However, to ensure good quality structural concrete, it is important to investigate other parameters such as the elasticity modulus and tensile strength.

The elasticity modulus, associated with the control of structural deformations, can be measured by mechanical tests or predicted by equations proposed by standards. Hence, this research consisted of investigating the influence of recycled concrete aggregates (RCA) and waste porcelain aggregates (WPA) in mechanical properties of $20 \mathrm{MPa}$ and $40 \mathrm{MPa}$ strength class concretes, verifying if there are any similarities between the predicted values calculated by different standards, comparing the predicted values with measured results and evaluating the compressive strength of concretes cast in cylindrical and cubic specimens.

To validate the results, an ANOVA analysis was performed to understand the significant differences between the averages of measured results. In the compressive strength test, it was found that recycled concrete aggregates (RCA) affected the compressive strength of $20 \mathrm{MPa}$ concretes but did not affect the compressive strength of $40 \mathrm{MPa}$ concretes. Waste porcelain aggregates (WPA), on the other hand, did not affect the compressive strength of $20 \mathrm{MPa}$ or $40 \mathrm{MPa}$ concretes. It is believed that this is due to the physical and chemical similarities porcelain waste has with natural aggregates [32].

In the measured elasticity modulus investigation, it was found that RCA and WPA significantly affected the elasticity moduli of both $20 \mathrm{MPa}$ and $40 \mathrm{MPa}$ concretes. In this case, the concrete elasticity modulus with $30 \%$ of RCA was superior to the reference concrete modulus, which can be justified by the better adhesion between the cement paste and the mortar adhered to the particles of the recycled aggregates.

The elasticity modulus of concretes with WPA was higher than the reference modulus of elasticity. It is believed that the cause of this increase is due to the rough surface of non-polished porcelain that allows the paste to adhere easily and thus benefit the modulus of elasticity.

The elasticity modulus and splitting tensile strength calculated by the consulting standards [19-22] resulted in different values because each standard recommends different values of coefficients and deviation. In general, the decreasing order of predicted elasticity modulus is those calculated by: fib Model Code 2010 [20], NBR 6118:2014 [19], Eurocode 2:2004 [21] and ACI 318:2014 [22]. The decreasing order of predicted splitting tensile strength is calculated by: NBR 6118:2014 [19], fib Model Code 2010 [20], ACI 318:2014 [22] and Eurocode 2:2004 [21].

The measured elasticity moduli of conventional concretes (C20 and C40) were lower than the predicted moduli calculated by fib Model Code 2010 [20] and NBR 6118:2014 [19], indicating a lack of safety of serviceability from these standards. On the contrary, the measured elasticity modulus from conventional concretes was superior to those predicted by ACI 318:2014 [22] and Eurocode 2:2004 [21].

Measured splitting tensile strength results of $40 \mathrm{MPa}$ concretes were superior to all predicted values, indicating safety from all the consulting standards. On the contrary, for most $20 \mathrm{MPa}$ concretes, measured splitting tensile strength was lower than the values predicted by ACI 318:2014 [22], indicating a lack of safety by the American standard.

Different values of $\alpha_{\mathrm{E}}$ were considered in modulus calculations, and it was found that, for concretes with measured elasticity modulus lower than the modulus predicted with $\alpha_{\mathrm{E}}=1.20$ (basalt), when it was predicted with $\alpha_{\mathrm{E}}=1.00$ (granite), the modulus was above them as expected.

An ANOVA analysis was also performed to verify whether the change in geometry of the specimens affects the compressive strength of the studied concretes. The geometry changes substantially affected the compressive strength of $20 \mathrm{MPa}$ concrete but did not affect the strength of $40 \mathrm{MPa}$ concrete. The results found in this research indicate that the effect of specimen geometry is more significant in low-strength concretes.

In $20 \mathrm{MPa}$ concretes, the compressive strength of concrete cast in cubic specimens was superior to the compressive strength of concretes cast in cylindrical specimens. A possible cause would be the effect of containing the press plates that extend throughout the height of the cubes, but in the cylinders ends up not reaching part of the height. 
Author Contributions: Project Administration, Conceptualization, Methodology, and Supervision, A.E.P.G.d.A.J.; Writing-Original Draft, Data curation, and Validation, I.S.G.C.; Writing-Review, Editing and Supervision, L.L.P.; and Software and Formal Analysis, N.C.S.F. All authors have read and agreed to the published version of the manuscript.

Funding: This study was financed in part by the Coordination for the Improvement of Higher Level Personnel-Brazil CAPES (Coordenação de Aperfeiçoamento de Pessoal de Nível Superior-Brasil CAPES) (Finance Code 001). The authors thank to Pontifical Catholic University of Campinas and to FAPESP through the process 2014/20486-8 and 2020/12709-8, to LafargeHolcim and to GCP Applied Technology.

Conflicts of Interest: We declare that we do not have any commercial or associative interest that represents a conflict of interest in connection with the work submitted and the results.

\section{References}

1. Kisku, N.; Joshi, H.; Ansari, M.; Panda, S.; Nayak, S.; Dutta, S.C. A critical review and assessment for usage of recycled aggregate as sustainable construction material. Constr. Build. Mater. 2017, 131, 721-740. [CrossRef]

2. Behera, M.; Bhattacharyya, S.; Minocha, A.; Deoliya, R.; Maiti, S. Recycled aggregate from C\&D waste \& its use in concrete-A breakthrough towards sustainability in construction sector: A review. Constr. Build. Mater. 2014, 68, 501-516. [CrossRef]

3. Silva, R.V.; De Brito, J.; Dhir, R.K. Establishing a relationship between modulus of elasticity and compressive strength of recycled aggregate concrete. J. Clean. Prod. 2016, 112, 2171-2186. [CrossRef]

4. ABRELPE (Associação Brasileira de Empresas de Limpeza Pública e Resíduos Especiais). Panorama de Resíduos Sólidos no Brasil; ABRELPE: São Paulo, Brazil, 2017.

5. Moreira, L.H.H. Avaliação da influência da origem e do tratamento dos agregados reciclados de resíduos de construção e demolição no desempenho mecânico do concreto estrutural. Dissertação de Mestrado, Escola Politécnica-Universidade de São Paulo, São Paulo, Brazil, 2010; p. 106.

6. Wang, Y.; Zhang, H.; Geng, Y.; Wang, Q.; Zhang, S. Prediction of the elastic modulus and the splitting tensile strength of concrete incorporating both fine and coarse recycled aggregate. Constr. Build. Mater. 2019, 215, 332-346. [CrossRef]

7. Martínez-Lage, I.; Vázquez-Burgo, P.; Velay-Lizancos, M. Sustainability evaluation of concretes with mixed recycled aggregate based on holistic approach: Technical, economic and environmental analysis. Waste Manag. 2020, 104, 9-19. [CrossRef]

8. Lu, W.; Yuan, H. A framework for understanding waste management studies in construction. Waste Manag. 2011, 31, 1252-1260. [CrossRef]

9. Limbachiya, M.; Meddah, M.S.; Ouchagour, Y. Use of recycled concrete aggregate in fly-ash concrete. Constr. Build. Mater. 2011, 27, 439-449. [CrossRef]

10. Pepe, M.; Filho, R.D.T.; Koenders, E.A.; Martinelli, E. Alternative processing procedures for recycled aggregates in structural concrete. Constr. Build. Mater. 2014, 69, 124-132. [CrossRef]

11. Dilbas, H.; Çakır, Ö.; Şimşek, M. Recycled Aggregate Concretes (RACs) for Structural Use: An Evaluation on Elasticity Modulus and Energy Capacities. Int. J. Civ. Eng. 2016, 15, 247-261. [CrossRef]

12. Gujel, D.A.; Kazmierczak, C.S.; Masuero, J.R. Stress-strain curve of concretes with recycled concrete aggregates: Analysis of the NBR 8522 methodology. Rev. IBRACON Estrut. Mater. 2017, 10, 547-567. [CrossRef]

13. Tibbetts, C.M.; Perry, M.C.; Ferraro, C.C.; Hamilton, H.R. (Trey). Aggregate Correction Factors for Concrete Elastic Modulus Prediction. ACI Struct. J. 2018, 115, 931-941. [CrossRef]

14. Guadagnuolo, M.; Donadio, A.; Tafuro, A.; Faella, G. Experimental Behavior of Concrete Columns Confined by Transverse Reinforcement with Different Details. Open Constr. Build. Technol. J. 2020, 14, 250-265. [CrossRef]

15. Wu, K.-R.; Chen, B.; Yao, W.; Zhang, N. Effect of coarse aggregate type on mechanical properties of high-performance concrete. Cem. Concr. Res. 2001, 31, 1421-1425. [CrossRef]

16. Araujo, S.S.; Guimarães, G.N.; Geyer, A.L.B. Influência do tipo de medição na determinação do módulo estático de elasticidade do concreto. IBRACON Struct. Mater. J. 2012, 5, 555-575.

17. Beushausen, H.; Dittmer, T. The influence of aggregate type on the strength and elastic modulus of high strength concrete. Constr. Build. Mater. 2015, 74, 132-139. [CrossRef] 
18. Dos Santos, A.C.; De Arruda, A.M.; Silva, T.J.; Vitor, P.D.C.P. Estudo comparativo entre valores te?ricos e resultados experimentais de $\mathrm{m}$ ?dulo de elasticidade de concretos produzidos com diferentes tipos de agregado graúdo. Ambiente Construído 2017, 17, 281-294. [CrossRef]

19. ABNT. NBR 6118: Projeto de Estruturas de Concreto-Procedimento; ABNT (Associação Brasileira de Normas Técnicas): Rio de Janeiro, Brazil, 2014; p. 256.

20. Federation internationale du beton. fib Model Code for Concrete Structures; Ernst \& Sohn: Hoboken, NJ, USA, 2010.

21. CEN (European Committee for Standardization). Eurocode 2: Design of Concrete Structures_Part 1-1: General Rules and Rules for Buildings (EN 1992-1-1); fib international: Lousane, Switzerland, 2004; p. 227.

22. ACI (American Concrete Institute). ACI 318-2014: Building Code Requirements for Structural Concrete (ACI 318-14) and Commentary (ACI 318R-14); American Concrete Institute: Farmington Hills, MI, USA, 2014; p. 519.

23. ABNT. NBR 8953: Concreto Para Fins Estruturais-Classificação Pela Massa Específica, Por Grupos de Resistência e Consistência; ABNT (Associação Brasileira de Normas Técnicas): Rio de Janeiro, Brazil, 2015; p. 7.

24. ABNT. NBR NM 248: Agregados-Determinação da Composição Granulométrica; ABNT (Associação Brasileira de Normas Técnicas): Rio de Janeiro, Brazil, 2003; p. 13.

25. Helene, P.; Terzian, P. Manual de Dosagem e Controle do Concreto; Editora Pini: São Paulo, Brazil, 1992.

26. ABNT. NBR 15116: Agregados Reciclados de Resíduos Sólidos da Construção Civil-Utilização em Pavimentação e Preparo de Concreto Sem Função Estrutural—Requisitos; ABNT (Associação Brasileira de Normas Técnicas): Rio de Janeiro, Brazil, 2004; p. 18.

27. Devore, J.L. Multifactor Analysis of Variance. In Probability \& Statistic: For Engineering and the Science, 8th ed.; Brooks/cole: São Luis, CA, USA, 2012; pp. 419-465.

28. ACI (American Concrete Institute). ACI 301-2010: Specifications for Structural Concrete; American Concrete Institute: Farmington Hills, MI, USA, 2010; p. 81.

29. ABNT. NBR 8522: Concreto—Determinação dos Módulos Estáticos de Elasticidade e de Deformação à Compressão; ABNT (Associação Brasileira de Normas Técnicas): Rio de Janeiro, Brazil, 2017; p. 26.

30. Charles, M.J.; Gary, H.M.; Carey, S.R. Data Analysis: A Model Comparison Approach to Regression, ANOVA, and Beyond, 3rd ed.; Routledge: New York, NY, USA, 2017; ISBN 9781315744131.

31. Pérez-Benedicto, J.A.; Del Río-Merino, M.; Peralta-Canudo, J.L.; Mata, M.D.L.R.-L. Características mecánicas de hormigones con áridos reciclados procedentes de los rechazos en prefabricación. Mater. Constr. 2011, 62, 25-37. [CrossRef]

32. Campos, M.A.; Paulon, V.A. Utilização de agregados alternativos de isoladores elétricos de porcelana em concretos. Concreto y Cemento. Investig. Desarro. 2015, 7, 30-43.

33. Ferreira, L.; Ribas, L.; De Souza, V.C.; Bragança, S.R. Avaliação da reutilização de isoladores elétricos de porcelana em cerâmicas triaxiais. In Proceedings of the $23^{\circ}$ Congresso Brasileiro de Engenharia e Ciência dos Materiais, Foz do Iguaçu, Brazil, 4-8 November 2018.

34. Hamassaki, L.T.; Santos, R.F.C. Corpos de prova: Soluções Inovadoras. In Revista Notícias da Construção; SINDUSCON: São Paulo, Brazil, 2013.

35. Mehta, P.K.; Monteiro, P.J.M. Concreto: Microestrutura, Propriedades e Materiais, 2nd ed.; IBRACON: São Paulo, Brazil, 2014; p. 782, ISBN/ISSN 978-85-98576-21-3.

36. Watanabe, K.; Niwa, J.; Yokota, H.; Iwanami, M. Experimental Study on Stress-Strain Curve of Concrete Considering Localized Failure in Compression. J. Adv. Concr. Technol. 2004, 2, 395-407. [CrossRef]

37. Muciaccia, G.; Rosati, G.; Di Luzio, G. Compressive failure and size effect in plain concrete cylindrical specimens. Constr. Build. Mater. 2017, 137, 185-194. [CrossRef]

38. Kaish, A.; Jamil, M.; Raman, S.N.; Zain, M. Axial behavior of ferrocement confined cylindrical concrete specimens with different sizes. Constr. Build. Mater. 2015, 78, 50-59. [CrossRef]

39. Sinaie, S.; Heidarpour, A.; Zhao, X.; Sanjayan, J. Effect of size on the response of cylindrical concrete samples under cyclic loading. Constr. Build. Mater. 2015, 84,399-408. [CrossRef]

40. Neville, A.N. Propriedades do Concreto, 5th ed.; Editora Bookman: São Paulo, Brazil, 2015; p. 912, ISBN-13 978-8582603659.

41. Gyurkó, Z.; Nemes, R. Specimen Size and Shape Effect on the Compressive Strength of Normal Strength Concrete. Period. Polytech. Civ. Eng. 2020, 64, 276-286. [CrossRef]

42. Soares, D.; De Brito, J.; Ferreira, J.G.; Pacheco, J. Use of coarse recycled aggregates from precast concrete rejects: Mechanical and durability performance. Constr. Build. Mater. 2014, 71, 263-272. [CrossRef] 
43. Manzi, S.; Mazzotti, C.; Bignozzi, M.C. Preliminary Studies on the Effect of C\&DW on the Long-Term Properties of Sustainable Self-Compacting Concrete. CONCREEP 2015, 10, 1554-1560. [CrossRef]

44. Milhomem, P.M.; Silva, J.M.; Costa, P.S. Avaliação das propriedades mecânicas do concreto produzido com resíduo de isoladores elétricos de porcelana. REEC—Rev. Eletrônica Eng. Civ. 2017, 14, 238-247. [CrossRef]

45. De Argollo Ferrão, A.M.; Campos, M.A.; Paulon, V.A. Argamassa com agregados de isoladores elétricos de porcelana: Influência da camada de esmalte nas propriedades mecânicas e de durabilidade. In Proceedings of the $60^{\circ}$ Congresso Brasileiro de Cerâmica, Águas de Lindóia, São Paulo, Brazil, 15-18 May 2016.

(C) 2020 by the authors. Licensee MDPI, Basel, Switzerland. This article is an open access article distributed under the terms and conditions of the Creative Commons Attribution (CC BY) license (http://creativecommons.org/licenses/by/4.0/). 